\title{
Implementation of an Electronic Alert for Improving Adherence to Diabetic Foot Exam Screenings in Type 2 Diabetic Patients in Primary Care Clinics
}

Ruby Denson

University of St. Augustine for Health Sciences, r.denson@usa.edu

DOI: https://doi.org/10.46409/sr.CHJT9855

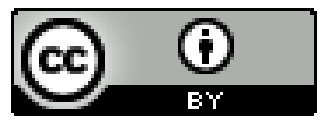

This work is licensed under a Creative Commons Attribution 4.0 License.

Follow this and additional works at: https://soar.usa.edu/scholprojects

Part of the Endocrinology, Diabetes, and Metabolism Commons, Family Practice Nursing Commons, Primary Care Commons, and the Software Engineering Commons

\section{Recommended Citation}

Denson, R. (2020). Implementation of an Electronic Alert for Improving Adherence to Diabetic Foot Exam Screenings in Type 2 Diabetic Patients in Primary Care Clinics. [Doctoral project, University of St Augustine for Health Sciences]. SOAR @ USA: Student Scholarly Projects Collection. https://doi.org/ 10.46409/sr.CHJT9855

This Scholarly Project is brought to you for free and open access by the Student Research at SOAR @ USA. It has been accepted for inclusion in Student Scholarly Projects by an authorized administrator of SOAR @ USA. For more information, please contact soar@usa.edu, erobinson@usa.edu. 
Implementation of an Electronic Alert for Improving Adherence to Diabetic Foot Exam Screenings in Type 2 Diabetic Patients in Primary Care Clinics

Ruby Ellis Denson, MSN, RN, FNP-BC

School of Nursing, University of St. Augustine for Health Sciences

This Manuscript Partially Fulfills the Requirements for the

Doctor of Nursing Practice Program and is Approved by:

Sarah M. I. Cartwright, DNP, MSN-PH, BAM, RN-BC, CAPA, FASPAN

Tawana Tucker, DNP, MPH, RN

December 01, 2020 


\section{University of St. Augustine for Health Sciences \\ DNP Scholarly Project \\ Signature Form}

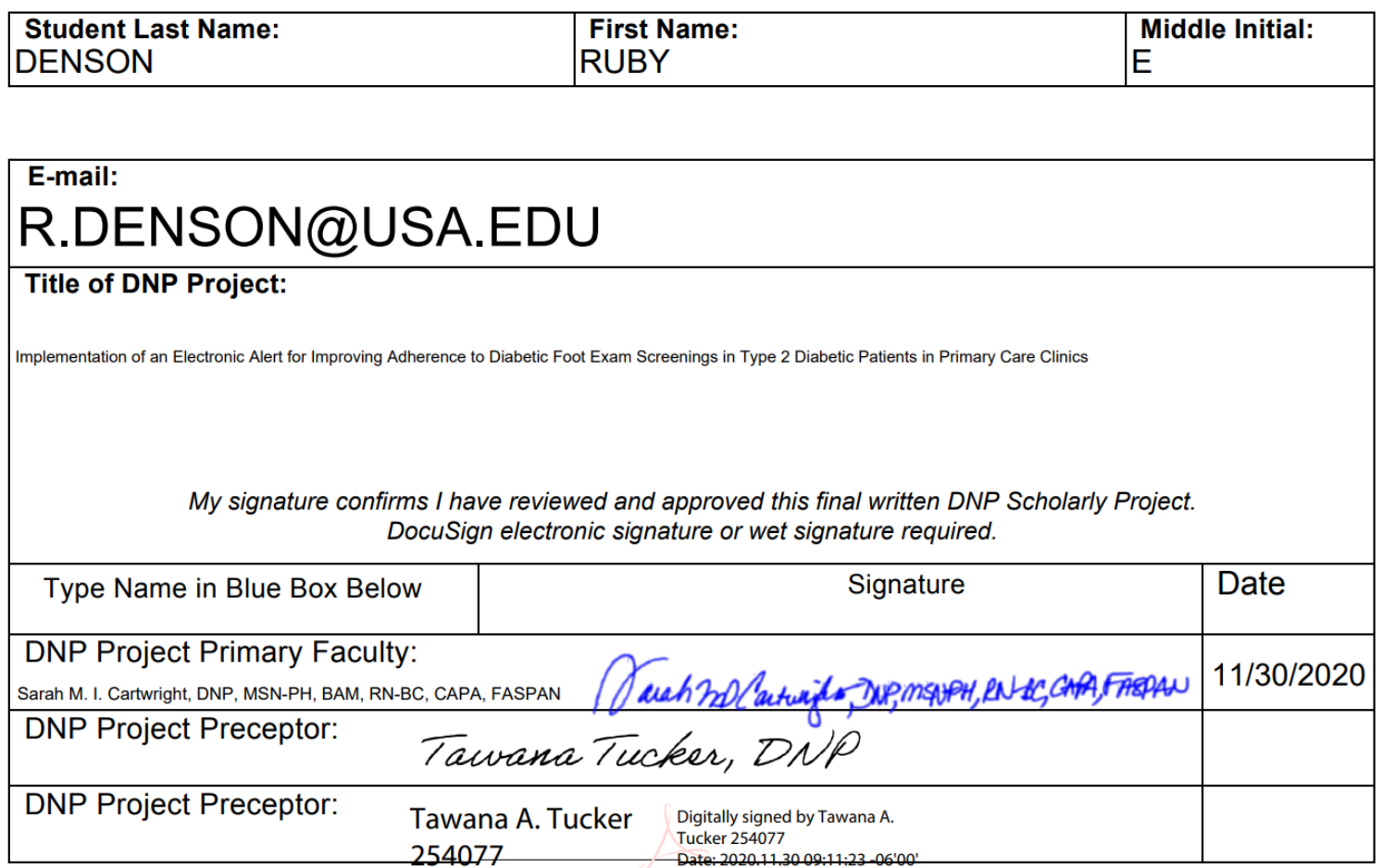




\begin{abstract}
Practice Problem: Patients with type 2 diabetes mellitus (T2DM) are at an increased risk of complications including foot ulcerations (Harris-Hayes et al., 2020). Preventive care is essential for the early detection of foot ulcers but despite the advantages of preventive screening, a limited number of primary care providers perform annual foot exams (Williams et al., 2018).

PICOT: The clinical question that guided this project was, "In adult patients with T2DM receiving care in a primary care setting, will the implementation of an electronic clinical reminder alert (ECR) increase provider adherence to performing an annual diabetic foot exam and risk assessment, compared to adherence rate pre alert implementation, in 30 days?"

Evidence: Evidence indicates that ECR alerts to remind providers to perform foot exams improve provider adherence to perform annual foot exams.

Intervention: An ECR alert was implemented to remind providers to perform an annual diabetic foot exam to increase provide adherence.

Outcome: Twenty-three patients had a completion rate of $46 \%$ for their annual diabetic foot exam pre intervention implementation and 45 patients had a completion rate of $56.25 \%$ post intervention implementation. There was no statistical significance noted but an increase in provider adherence in performing foot exams, which suggests clinically significant outcomes. Conclusion: Annual foot exams and an ECR alert to remind providers to perform foot exams on people with diabetes can help improve health outcomes in diabetic patients.
\end{abstract}




\section{Implementation of an Electronic Alert for Improving Adherence to Diabetic Foot}

\section{Exam Screenings in Type 2 Diabetic Patients in Primary Care Clinics}

Patients with type 2 diabetes mellitus (T2DM) are at an increased risk of complications, including foot ulceration and lower extremity amputations (Harris-Hayes et al., 2020). Thirtythree percent of the multi-billion-dollar economic burden of diabetes is related to foot complications (Joret et al., 2019). The American Diabetes Association (ADA) clinical practice guidelines recommend that a yearly comprehensive foot exam detect foot ulcers and amputation (ADA, 2020). Healthcare providers can prevent Diabetic foot ulcers (DFUs) by performing early screening and treatment of vascular and peripheral neuropathy problems (Williams et al., 2018). The purpose of this evidence-based practice change project aims to increase provider adherence to performing a foot exam by implementing a clinical decision support system (CDSS) such as an electronic clinical reminder (ECR) alert. This alert would remind providers to capture early diabetic foot changes, which would increase the likelihood of therapeutic interventions.

\section{Significance of the Practice Problem}

Diabetic foot ulcers are the leading cause of non-traumatic lower extremity amputations and negatively impact the healthcare system and society (Centers for Disease Control and Prevention [CDC], 2019; Lin et al., 2019). DFUs are a significant cause of mortality and morbidity and directly impact patients and families' quality of life (Maurer et al., 2020; Polonsky et al., 2018). The loss of mobility associated with foot ulcers affects the patient's ability to perform daily activities and can also lead to anxiety and depression (CDC, 2020; Vileikyte et al., 2005). Additionally, DFUs can financially, emotionally, and physically impact the family unit. High medical costs associated with frequent hospitalizations and medical appointments and lost 
work wages caused by depression and loss of mobility can also negatively affect the person's family unit with diabetes (CDC, 2020).

The prevalence of diabetes exceeds 422 million individuals globally (World Health Organization, 2020). Approximately 34 million Americans have diabetes (CDC, 2019). In the United States, the financial expenditure related to diabetes is approximately $\$ 327$ billion (CDC, 2020). Statistics for Mississippi's state indicate that approximately 289,000 people are diabetic (CDC, 2020), costing the state over $\$ 2.74$ billion to treat the disease and its related complications (CDC, 2020). Locally, at a Mississippi Veterans Affairs (VA) hospital, it costs roughly $\$ 47,000$ to treat a veteran who is diagnosed with a DFU (Boyle, 2020).

More than $80 \%$ of lower-extremity amputations begin with foot ulcers, with nearly $24 \%$ leading to limb amputation within six to eight months of the initial evaluation (Pemayun et al., 2015). The cost of caring for patients with a DFU is about five times more than patients without a foot ulcer, due to frequent emergency room visits and more extended hospital stays (Kurowski et al., 2015). Comprehensive diabetic foot exams that include assessment of the loss of protective sensation are an integral part of preventing new and recurrent foot ulcers (Craig et al., 2014). Most foot ulcers are avoidable (Nteleki \& Njokweni, 2015). Unfortunately, despite the documented advantages of preventive screenings, few primary care providers utilize the clinical practice guidelines for performing foot exams annually or more regularly (Williams et al., 2018).

\section{PICOT Question}

The clinical question that guided this project is: In adult patients with T2DM receiving care in a primary care setting, will the implementation of an electronic clinical reminder (ECR) alert increase provider adherence to performing an annual diabetic foot exam and risk assessment, compared to adherence rate pre ECR alert implementation, in 30 days? This 
evidence-based practice project's target population included adults 18 years and older with T2DM seeking care in five primary care clinics in the VA hospital. The exclusion criteria were individuals younger than 18 years of age or without a diagnosis of T2DM. The project's intervention was the implementation of an ECR alert for healthcare providers to perform a foot exam and the corresponding education on the purpose of the alert, the content of the annual foot exam, and the need for annual exam adherence. The project manager reviewed a report of the External Peer Reviewers Performance (EPRP) regarding yearly diabetic foot exams performed by the primary care providers. The report showed that provider adherence to foot screenings at the beginning of the second quarter of the year was $67 \%$, compared to the national benchmark for foot examinations in T2DM patients, which is $85 \%$ or higher.

The proposed outcome for this evidence-based practice change was a $\geq 30 \%$ increase in provider adherence to performing foot exams after the implementation of an ECR alert over 30 days. The goal was for all T2DM patients to receive one annual exam. The project manager reduced the timeline for implementing this evidence-based practice change project to 30 days due to time constraints.

\section{Framework and Change Theory}

The project manager used Lewin's theory of change to outline the process of change. Lewin's change theory (1951) suggests that change happens in three stages: unfreezing, moving, and refreezing. The unfreezing phase's primary goal is to help the targeted population (staff) become ready and open to receiving change (increasing driving forces). The unfreezing step involves identifying that a change is needed. This occurred when the project manager reviewed the EPRP report to assess adherence to documenting foot exams. The project manager found the level of commitment to performing the foot exams was below the benchmark of $85 \%$. The EPRP 
report showed a gap in compliance and the need for change. In preparation for the change, the project manager solicited buy-in from the stakeholders. Key stakeholders' buy-in is essential to activating the change process. Lewin's change theory suggested that an evidence-based change should be slowly introduced to the staff to establish general awareness and help in the unfreezing stage (Lewin, 1951).

The second phase in Lewin's change theory allows change to take place. The moving stage involved developing and implementing the ECR alert. During this phase, weekly and biweekly meetings with stakeholders, multidisciplinary team members, providers, and staff occurred; this ensured that all involved understand the project's vision, goals, and directions. All education and training sessions were held during this phase, led by the DNP student (project manager). Shirey (2013) emphasized that clear and concise communication must be provided to all participants, related to the rationale for the anticipated change, benefits of the change, expected results, and staff engagement to increase buy-in.

The last phase occurs when the evidence-based change is implemented and becomes the organizations' standard of practice (Lewin, 1951). In this phase, the difference becomes incorporated and an accepted part of the organizational culture because providers become comfortable developing the new habit and reduce resistance to change further (Lewin, 1951). During this phase, the project manager identified and recognized any factors, which could impede the changes (restraining forces), that will take place and implement all other strategies (Shirey, 2013).

\section{Evidence Search Strategy}

A literature search related to the clinical question was completed by the project manager using the following electronic digital databases: University of Saint Augustine library, CINAHL, 
ProQuest, PubMed, Medline, EBSCOhost, and Google Scholar. The project manager applied to the search the limiters of the articles being written in English and the last six years and including current evidence that addresses the PICOT question. The inclusion criteria were that the articles had to include information related to diabetic foot exams, healthcare providers performing diabetic screenings, primary care settings, and diabetic foot screening tools. The exclusion criteria were articles written more than ten years ago, studies that did not occur in the United States, and studies written in Spanish or other languages. The initial search yielded over $8,380,000$ results. The project manager narrowed the investigation by applying the limiters above and reviewing the articles' relevance to the PICOT question; this resulted in 49 articles. The project manager for eligibility assessed these 49 articles and excluded 29 since they were not relevant to the clinical question (see the PRISMA diagram in Figure 1).

\section{Evidence Search Results and Evaluation}

The project manager assessed forty-nine articles for relevance during the final electronic database search. Twenty-nine of these did not include information related to the clinical question and were excluded. The 20 articles remaining were graded for the strength of evidence using the Johns Hopkins Nursing Evidence-Based Practice Rating Scale by the project manager.

The project manager noted that 9 of the studies were non-experimental in design, and several were quality improvement projects. Five of the articles were graded by the project manager as high quality with clear aims and objectives, consistent results across multiple settings and consistent recommendations based on the literature review that included scientific evidence (Dang \& Dearholt, 2018). Three of the articles were graded as good quality because of their aims and objectives, a single setting, and sufficient sample size (Dang \& Dearholt, 2018). One article was graded low because of its insufficient sample size (Dang \& Dearholt, 2018). 


\section{Themes from the Evidence}

This section offers the similarities and differences noted in the evidence. The themes include risks, complications, and evidence-based strategies. The evidence is summarized, explaining the themes and subthemes related to DFEs. The identified themes and studies are related to diabetic foot exams, interdisciplinary team, patient education, and ECRs and are components of the PICOT question. The synthesis of evidence from the studies revealed that clinical decision support (CDS) improved the healthcare provider's clinical decision-making (Buschkoetter et al., 2019; Pocuis et al., 2017; Williams et al., 2018). The main ideas and the strength of grading are noted in Appendix A.

There is a gap between evidence-based practice and care delivery in primary care clinics for diabetes (Kadu \& Stolee, 2015; Shelby et al., 2020). This gap limits healthcare providers' knowledge levels of and opportunities in primary care practices to supply necessary interventions, education, early detection, and prevention. In response to the question that guided this project, the literature supports the use of an ECR via the EHR to prompt the provider to perform a comprehensive diabetic foot exam in a clinical setting, increasing adherence to performing the foot exam requirements (Kumar et al., 2018; Pocuis et al., 2017; Williams et al., 2018). Healthcare providers who engage and endorse the ECR alert will improve adherence, ultimately enhancing their potential to capture existing or emerging foot injuries or illnesses in this population. This evidence-based practice change project will evaluate provider adherence in the diabetic foot exam's performance using a pre and post intervention data set to compare rates of implementation 30 days before the changes to 30 days post intervention.

Hingorani et al. (2016) outlined the routine management of the diabetic foot in a clinical practice guideline by the Society for Vascular Surgery in collaboration with the American 
Podiatric Medical Association and the Society for Vascular Medicine. A summary of recommendations for the prevention of DFUs includes that patients with diabetes should undergo annual interval foot exams by their providers with training in foot care (Hingorani et al., 2016). According to Bus et al. (2016), the International Working Group on the Diabetic Foot (IWGDF) states that healthcare providers should perform a yearly diabetic foot exam to identify a person at risk of foot ulceration. The authors developed recommendation of IWGDF guidance based on the Grading of Recommendations Assessment, Development, and Evaluation (GRADE) system for grading evidence (Guyatt et al., 2011). The GRADE strength was substantial; however, the quality of evidence was low. The evidence in the studies for screening was insufficient (Bus et al., 2016) (see a summary of systematic reviews in Appendix B).

Williams et al. (2018) reported that nearly $50 \%$ of diabetic foot complications could be prevented with proper education by the healthcare provider. Goulding and Bale (2019) demonstrated how the implementing a combination of education methods — such as the audit and feedback along with a prompted reminder-yielded an increase in provider performed foot exams.

\section{Electronic Clinical Reminder Alert}

Integrated reminders in the clinical healthcare setting have become common in introducing the EHR (Backman et al., 2017). The literature supports the findings that a clinical reminder system helps providers deliver quality care to patients for both preventative healthcare and management of chronic conditions, ensure timely clinical interventions, and improve documentation of foot exams (Nuti et al., 2015; Pocuis et al., 2017; Williams et al., 2018; Wrobel et al., 2011; Wu et al., 2019). 
Ivers et al. (2012) found that the audit and feedback approach improved healthcare providers' professional practice and behavior change. Prompts such as laminated pocket cards, newsletters on clinic communication boards, and electronic alerts encouraged behavior change (Goulding \& Bale, 2019). The literature shows that implementing desirable clinical behaviors through innovative formats of ECRs such as "tickers and the pop-up box" creates a change from the routine reminder (Backman et al., 2017; Wrobel et al., 2011; Wu et al., 2019). However, some studies revealed that adding extra reminders can risk overwhelming the provider with too many tasks, resulting in alert fatigue (Backman et al., 2017; Black \& Stutler, 2018; Kumar et al., 2018).

\section{Foot Exams}

People with diabetes are at high risk of nerve and vascular damage resulting in loss of protective sensation in the feet, poor healing, and reduced circulation (Indian Health Service, 2020). The literature supports that careful inspection, systematic screening, and adherence to preventive and follow-up care of the feet substantially reduce mortality from foot complications (Alford et al., 2018; Tariq \& Cruz, 2015; Wexler et al., 2020).

\section{Healthcare Provider Adherence}

Provider adherence to the recommended diabetes clinical practice guidelines is mostly implied and not always explicitly outlined in the literature. Moreover, the practice of adherence promotes early detection and intervention to decrease the risk of limb loss (Schaper et al., 2017). Within the primary care clinics at the VA, diabetic foot exams are performed inconsistently and do not adhere to evidence-based screening guideline recommendations for annual foot exams. Notably, primary care providers inconsistently perform and document the same. 
Despite the established benefits of adhering to the clinical practice guidelines for foot care, a small number of providers adhere to the evidence-based guidelines to perform foot exams (Buschkoetter et al., 2019; Tariq \& Cruz., 2015; Williams et al., 2018). Providers indicate the barriers for the foot exam adherence: alert fatigue, the complexity of the chronic disease, time, and money constraints (Kumar et al., 2018).

\section{Interdisciplinary Team}

Healthcare professionals should not be expected to solely manage the multifaceted aspects of care management of diabetes complications (Nteleki \& Njokweni, 2015). In 2017, the Department of Veterans Affairs (VA) released a directive that outlined the scope of care deemed necessary to prevent and treat foot complications and amputations (VA, 2017). The VA endorsed the need for a comprehensive approach that included multidisciplinary teams in the performance of foot exams to reduce the risk of foot ulcers and complications (VA, 2017).

A consistent theme cited in the literature is that the cornerstones of preventing of foot ulcers and complications involve a multidisciplinary team approach. The interdisciplinary team approach would ensue the following early identification and examination of the at-risk foot, regular inspections, and patient and family education; this would result in early access to care, including a healthcare provider visit, obtaining an education, and referrals for specialty care when needed (Nteleki \& Njokweni, 2015; Quach et al., 2019; Schaper et al., 2017; Vitale et al., 2020).

\section{Provider and Staff Education}

A frequently cited theme that denoted a call for improving adherence to performing foot exams for diabetic patients was the educational knowledge gap of the providers, staff, and patients and their families (Buschkoetter et al., 2019; Quach \& Goldschmidt, 2019; Williams et 
al., 2018). Allen et al. (2016) developed a focus group to determine patient educational needs such as awareness of the importance of undergoing foot exams by the provider and of self-foot inspections.

Education is an essential part of both the project's planning and intervention stages (Allen et al., 2016; Edupuganti et al., 2019; Green-Morris, 2019; Quach \& Goldschmidt, 2019). Alford et al. (2018) stated the importance of provider education on the functionalities of the CDS and the appropriate use of the EHR to help close the gap for preventive care and management of T2DM.

\section{Practice Recommendations}

Clinical decision support has been recognized as an approach to provide safe and effective diabetes management (Kaushal et al., 2013). Jia et al. (2016) found evidence that supported the idea that using CDSS to provide alerts, reminders, or feedback to the patient can positively impact diabetes care. Quach and Goldschmidt (2019) evaluated a program process change to improve the completion of foot exams for patients with diabetes. The researchers used the templated CPRS-EHR to place electronic reminders to perform foot exams and provide appropriate follow-up foot care treatment (Quach \& Goldschmidt, 2019). The researchers also reported that the standardized documentation process improved accurate foot exams and early referrals for podiatry with high-risk foot complications (Quach \& Goldschmidt, 2019). Williams et al. (2018) implemented an electronic alert to remind providers to perform foot exams that resulted in $78 \%$ of reviewed patient charts showing improved provider compliance in the completion of foot exams. Both studies linked CDSS to evidence-based treatment guidelines that will increase provider compliance and reduce foot ulcers. Across the 20 articles reviewed, several of the researchers performed a pre and post intervention chart audit. 
Williams et al. (2018) and Quach and Goldschmidt (2019) compared the pre intervention data to the CDSS tool's post intervention data. Interval data was collected by the project manager at three, six, and nine months of post intervention implementation. The implications of the evidence-based practice change project results support the findings that the performance of an ECR alert to evidence-based treatment guidelines will increase provider compliance to performing foot exams.

\section{Project Setting}

The project manager conducted this practice change project at a Joint Commission accredited complexity level 1B facility that serves veterans in Mississippi and parts of Louisiana and Arkansas. The medical center has academic and medical school affiliation programs located in Mississippi and Alabama (Smith-Dikes \& Redd, 2014).

The medical center has 150 operating beds and provides primary, secondary, and tertiary medical, surgical, neurological, and psychiatric inpatient and outpatient care. The medical center serves over 125,000 patients and has more than 300,000 patient visits annually (VA, 2015a). The medical center has five outpatient primary care clinics located on-site and six community-based outpatient clinics in the neighboring area (VA, 2015a). The healthcare system supports innovation, empowerment, productivity, accountability, and continuous improvement. The bonds of collaboration among provider grow to provide quality healthcare in a convenient, responsive, cost-effective, and caring manner (VA, 2015b). The leaders are not quick to judge and punish employees, creating a just and fair culture (Sculli \& Hemphill, 2013).

\section{Strengths, Weaknesses, Opportunities, and Threats}

Diabetes is a multifaceted disease progression that requires complex care to prevent subsequent health complications (Gervera \& Graves, 2015). The project manager performed a 
strengths, weaknesses, opportunities, and threats (SWOT) analysis to assess the medical center's readiness for the evidence-based practice change project. In this project, an ECR alert was developed and implemented in the EHRs. The implementation of this tool provided healthcare providers with an ECR alert to perform a foot exam.

The strengths identified within the medical center included the following: leadership support; being a high-reliability organization (HRO); staff interest in improving veteran care; being a leader in EHR systems; availability of required equipment; and promotion of quality improvement practices and innovation by exploring ideas to improve quality healthcare for veterans.

The weaknesses identified included multifactorial inconsistencies in the documentation, implementation, and practice; the absence of standardizing the protocol for provider foot exams and referrals; and the absence of policies and available reference materials for provider foot exams. The opportunities included reducing readmission rates of patients with diabetes complications, reducing the incidence of foot ulcers and amputations, and improving communication among patients, family, and staff. The threats of the organization included the following: cost of treatment of foot ulcers and amputations; staffing turnover in primary care clinics; low patient satisfaction scores found in the Strategic Analytics for Improvement and Learning report; and poor staff satisfaction scores found in the All Employee Survey (see Appendix C for a summary of the SWOT analysis).

\section{Project Overview}

The healthcare system's overall mission is to serve America's veterans' needs by providing primary and specialized care and related medical and social support services. The medical center is an integrated healthcare system that ensures excellence in healthcare value, as 
defined by its patients, and in education and research. The medical center's mission is to provide quality healthcare for the veterans using the five core principles: Integrity (I), Commitment (C), Advocacy (A), Respect (R), and Excellence (E). The medical center's vision is to be a patientcentered healthcare system that provides comprehensive care for patients. This evidence-based practice change project aligns with the organization's stated mission and vision of improving the quality of care of the population through increased adherence to preventive care guidelines. The project's objectives are to increase adherence to the completion and documentation of annual diabetic foot exams in T2DM patients.

A previously performed organizational needs assessment indicated the need to improve provider adherence to completing foot examinations for diabetic patients. The project manager obtained information by utilizing the observational data from the quarterly external peer reviewer's performance (EPRP) report for the VA. This report highlighted the fact that the providers were inconsistent in performing routine annual diabetic foot exams. Further assessment of the current alert system indicated the absence of a reminder alert to prompt the providers to perform the foot exam.

This information warranted the completion of a gap analysis that revealed several findings: a) knowledge gap regarding the quarterly performance data of provider-performed foot exams; b) a knowledge gap of the providers locating documentation tool in the EHR for foot exams; c) and the lack of readily accessible ECR alert in the EHR for the provider to document annual foot exams. The needs assessment and gap analysis were performed and proved to help reveal the need to implement an ECR alert to remind providers to perform an annual foot exam for diabetic patients. 
This evidence-based practice change project aims to provide quality healthcare congruent with the medical center's mission of providing quality care for the served population. The vision of this project was to provide cost-effective patient-centered care through patient and staff empowerment. The use of innovation with the implementation of an ECR alert, staff accountability for the care provided, and the promotion of continuous quality improvement strategies, all of which are congruent with the medical center's overarching vision.

The short-term goals for this evidence-based practice change project included a $\geq 30 \%$ increase of adherence of provider performed foot exams over 30 days, and $90 \%$ or higher staff completion of training in the performance of foot exams within the first 30 days of the evidencebased practice change project. The overall short-term objectives were increased knowledge regarding the importance of performing foot exams and an increased rate of foot exams performed by providers after the ECR alert implementation.

The long-term goal for this evidence-based practice change project was to sustain adherence to annual foot exams performed by providers as evidence by documented improvement rates of $85 \%$ or greater on the EPRP quarterly reports. Ultimately, improvement in provider adherence to performing an annual foot exam should result in early detection of foot complications, timely podiatry referrals, and long-term prevention of foot ulcers and foot complications, resulting in cost savings for the facility.

Many healthcare organizations are adopting CDS systems to improve patient safety and to adhere to the meaningful use requirements (McCoy et al., 2014). As an HRO, the Department of Veterans Affairs has committed to moving to a system of vastly routine medical care. Risk avoidance and unintentional consequences associated with this project mirror the standards of HROs. The HRO standards include the "three key components, a) prevention of errors, b) 
detection of unavoidable errors by using a team process to readily identify, and c) the mitigation of errors that go undetected" (Joshi et al., 2014, p. 308).

An unintended consequence of implementing this evidence-based practice change project resulted in alert overrides when providers ignored the ECR alert's guidance and subsequently delayed improved patient outcomes. Another unintended consequence of implementing an ECR alert was alert fatigue from widespread use and dissemination in the EHR, limiting patient outcomes.

The areas of risk avoidance included eliminating communication barriers by ensuring provider and staff education, surveillance of workflow, and the development of organizational policies and procedures to sustain a culture of safety. Moreover, the designated clinic educator conducted staff and provider education and training and ongoing evaluations. The information technologist provided a written procedure for the ECR alert training to both providers and staff. Staff adherence to performing a foot exam after the ECR alert implementation was monitored in the VHA Support Service Center Capital Asset (VSSC) by the project manager and the assigned team member. The chief of primary care services monitored for non-adherence to the provider's alerts for continuous improvement and remedial training. The primary care service chief performed focused professional performance evaluations and ongoing professional performance evaluations as a means to evaluate clinical competency in a non-punitive manner (VA, n. d.). Additional risks considered were the loss of data for the facility and social or psychological issues that include the veteran feeling embarrassed about the diagnosis or discussing their feet.

\section{Project Plan (Method)}

The project manager used Lewin's theory of change (1951) to guide this practice change project. Lewin's approach demonstrates the driving forces needed to lead change (Nursing 
Theory, 2016). Lewin's change model offers a structured approach to identify a need for change, navigate through the change process, and achieve the desired goal. In the initial stage of unfreezing, the providers' failing the performance measure of conducting a yearly foot exam led to a change. Gaining stakeholders' buy-in was one step to increase awareness for a needed change at the facility. This process involved addressing the behavior(s) that led to the problem. It included brainstorming and collaborating with the interdisciplinary team members regarding the best way to resolve the practice problem.

This project began with the development of an interprofessional team. The team established guidelines and provided input in the project planning and implementation of staff and patient education and training. The project was led by the project manager, who identified the provider's level of adherence in performing foot exams and facilitated the team's integration of guidelines into the practice of the physicians, nurse practitioners, or physician assistants who cared for the T2DM patients. These providers were the ordering and referral providers for the care of the patients.

Additional team members included registered nurses and licensed practical nurses working in primary care clinics. These team members assisted the patient and support members in understanding the importance of the diabetic foot exam and working with the nursing staff to prepare the patient for the exam (take socks and shoes off, etc.). Additional assistance was provided by the certified diabetes educator who assisted the primary care clinic staff in developing and understanding appropriate educational materials and practice skills.

Finally, an IT specialist assisted the team by developing of the EHR's ECR alert following the design requirements, workflow assessment, and technical support. The facility preceptor and the DNP student completed the request in the Computerized Patient Record 
System (CPRS) for the Clinical Applicator Coordinator (CAC)/IT to add the ECR alert in the EHR. The CAC/IT role helped the medical center staff develop and implement operable alerts for the healthcare providers.

In the second stage, the IT specialist developed and implemented the ECR alert. The CAC/IT placed the ECR alert on the EHR's front page under the clinical reminders. The CAC/IT designed the ECR to create a ticker in the EHR when not completed. The ECR alert was not satisfied without the completion of the required components of the foot exam. During this state, the overarching goal was to strengthen the existing processes of ensuring the desired outcome of improved provider adherence to completing foot exams. The project manager continuously monitored staff attitudes and behaviors to ensure no disruptions in the typical workflow after the ECR alert implementation.

The refreezing stage involved the evaluation of the change. The designated clinic educator provided ongoing education of the ECR alert for all new staff training. The quality manager developed policies and procedures to assist the staff with the ECR alert document process. The continuous monitoring and improvement of the above ensured provider adherence in performing annual foot exams. The project aimed to an evidence-based practice change project to implement an ECR alert for primary care providers to increase their commitment to performing a diabetic foot exam yearly. A pretest was administered to the providers and nurses, assessing their knowledge of performing a diabetic foot exam, completing documentation, and using the 60 -second foot assessment tool. The project manager administered a post test to the same staff upon completion. The project manager compared the prediabetic foot exam rates of provider adherence to the post diabetic rates 30 days after completing the intervention to assess the outcomes. 
The Plan-Do-Study-Act (PDSA) cycle is a well-accepted quality improvement framework that can be used effectively in guideline implementation and evaluation involving multidisciplinary healthcare professionals (Marcellus et al., 2012). The project manager used the PDSA framework steps to plan, intervene, implement, and evaluate this evidence-based practice change project. The initial step in the PDSA cycle of the project was project selection and purpose. This step included a thorough description of the types of data and quality tools required for the project implementation and the reasons for their selection. The project manager examined the data from retroactive chart audits to identify weaknesses in the program processes or outcomes. The chart audit included a random selection of 50 patients $(n=50)$ with T2DM from the VSSC within the electronic medical records.

The Plan included meeting with the key stakeholders to ensure buy-in for the project, obtaining project approval from the Evidence-based Practice Review Committee (EPRC) and the facility, and forming a team for budget planning and brainstorming for the ECR alert implementation. During this phase, it was essential to ensure that all team members understood the project's vision, goals, and objectives. The project manager identified the organizational goals and performance measures, and outlined the strategies necessary to complete the administrative assessment and identified potential internal and external stakeholders.

The total budgeted cost for the evidence-based practice change project included both direct and indirect costs. The overall budget was reasonable despite the cost for the Certified Diabetes Educator's hours assisted with educating the patients, providers, nurse assistants, and other administrative staff. The DNP student hours for this project were included and counted as volunteer hours. The IT specialist educated the providers, RNs, nurse assistants, and other 
administrative staff on the clinical decision support tool implemented for the project (see the project budget in Table 1).

In the Do phase, the IT specialist developed the ECR alert. Designated clinic staff distributed educational materials during the educational sessions for the target audience. The project manager and the IT specialist educated the providers on using the ECR alert and documenting a foot exam in the EHR. The designated clinic staff and the project manager provided additional education and training during this PDSA phase. The providers received other educational outreach visits, for example, in their huddles and providers' meetings. The certified diabetes educator and the project manager taught the staff how to use the 60-second diabetic foot assessment tool properly. The designated clinic staff used the audit and feedback method to assess the knowledge learned. Implementation of the ECR alert occurred during this phase. Data was collected and assessed at 7-, 14-, 21-, and 30-day intervals to determine whether any changes led to project improvement outcomes. There were assessments and documentation of the tools to determine whether there were monitoring opportunities for improvement.

The Study portion of the PDSA was a review of the EHR's information, including the demographic data and incidence of expected to actual completion of foot exams performed by the provider. During this step, the interprofessional team members worked together to understand the results of the implemented changes. A description of any risks of avoidance included staff education barriers, workload concerns, workflow, process changes, and patient concerns.

The Act portion of the PDSA included post intervention evaluation of chart audits to determine whether there was a need for any changes to meet the project's goals. The project manager relied on open communication and feedback between the patients, interprofessional 
team members, staff, and providers to ensure the project ran smoothly. The final steps included the evaluation and dissemination of the information obtained during the project.

The project manager developed a timeline based on no unforeseen circumstances to empower the interprofessional team and secure key stakeholder' buy-in. Collaborative meetings were held with the USAHS faculty and facility preceptor weekly or bi-weekly, as needed. Team development and interprofessional collaboration meetings occurred in weeks one through three of the evidence-based change project. The submission to the EPRC happened during this period. In weeks four to six, the project manager held meetings with the key stakeholders. The team finalized the budget proposal by the end of week six. The interprofessional team's collaborative effort to meet and plan and develop the education and training materials for the providers and staff happened during weeks four to six. Additionally, in weeks four to six, the project manager scheduled the dates, times and locations for education and training.

Approval of the budget occurred during weeks seven to nine. The IT specialist began developing the ECR alert. The IT specialist provided the training and education on using the ECR alert during the first two weeks of implementation. Baseline data collection began after EPRC and facility's IRB approvals. Data was collected and evaluated following the timeline to determine provider adherence to perform foot exams after the ECR implementation. Weekly project information was communicated via WebEx and Microsoft Team meetings with follow-up emails and telephone calls by the project manager. The project manager monitored weekly to ensure deliverables remained on track. A concise explanation of the timeline for the evidencebased practice change project is outlined in Appendix D. 


\section{Evaluation Results}

This evidence-based change project aimed to evaluate whether provider adherence in performing diabetic foot exams for diabetic patients enrolled in primary care clinics would increase by $\geq 30 \%$ after an ECR alert implementation. The evidence-based project was evaluated by the outcome measures as described in the PICOT question. The following section discusses the recruitment and selection of participants, and it includes the inclusion and exclusion criteria, data collection and analysis processes, methods to determine the sustainability of the project, techniques to handle missing data, data security and storage, and reliability and validity of the data collected and evaluated.

\section{Recruitment and Selection of Participants}

This project evaluated the primary care provider's actions in a program process change to improve providers' adherence to performing foot exams. The primary care providers in the clinics were the primary participants of this evidence-based practice change project. The evidence-based practice change project was conducted in five primary care clinics by the project manager. Sixteen primary care providers were the primary participants, eight were physicians and eight were nurse practitioners. The project manager selected the provider participants due to the work performed with the target population. The project manager elected this selection method because it was easy, inexpensive, and convenient inaccessibility and proximity of the facility (Elfil \& Negida, 2017).

The project's inclusion criteria were adult patients with T2DM. The patients were all enrolled in a primary care clinic with a designated primary care provider. The exclusion criteria were patients younger than the age of 18 and diabetes. 
The interprofessional team's quality manager was instrumental in identifying the patients diagnosed with diabetes and enrolled in primary care clinics. The quality manager extracted the data from the VSSC of all the primary care provider's diabetic patients EHR, 30 days before intervention implementation, and 30 days following the intervention implementation. Additionally, the project manager developed a knowledge assessment questionnaire to assess provider and staff knowledge of foot exams pre and post intervention implementation. The rationale for using the pre and postintervention method was to produce a higher quality of evidence that revealed causal links between the interventions and outcomes of this evidencebased practice change project (Harris et al., 2006).

\section{Results}

The project manager collected demographic data to depict the participants in the project. The data collected included patient age, gender, and type of diabetes, participants by provider group, participants by clinic group, and podiatry referral. The data collected was displayed using frequency and percentage distribution figures.

The data in Figure 2 contains the frequency and percentage distribution of participants by age group. The green bars signify frequency and the red bars denotes percentage. The statistician calculated the mean, median, and standard deviation based on the age group. As presented in Figure 2, out of 135 participants, 12 (9\%) participants were in the 39-49 age group, 38 (28\%) in the 50-60 age group, $45(33 \%)$ in the 61-71 age group, $35(26 \%)$ in the $72-82$ age group, and 5 (4\%) in the 83-93 age group. The youngest participant was 39 years old and the oldest 90 . The

calculated mean age was 64.44, and the standard deviation was 10.42 (see Figure 2 for a detailed graph of the data). 
The data in Figure 3 designates the frequency and percentage distribution of participants by gender group. Each participant was categorized as male or female. 118 (87\%) participants were male and $17(17 \%)$ females (see Figure 3 for a detailed graph of the data).

The data in Figure 4 shows the frequency and percentage distribution of participants by the clinic group. Participants were assigned based on their clinic location: 16 (12\%) participants were assigned to the Yellow Clinic, 28 (21\%) to the Silver Clinic, 20 (15\%) to the Pink Clinic, $42(31 \%)$ to the Green Clinic, and $29(21 \%)$ to the Blue Clinic (see Figure 4 for a graph of the data).

The data in Figure 5 displays the participants' frequency and percentage distribution by provider group. Each participant was categorized as either a medical doctor or a nurse practitioner. The green bars indicate the frequency and the red bars display the percentage. As shown in Figure 5, 67 (49\%) participants belong to the medical doctor's group and 68 (51\%) to the nurse practitioner's (see Figure 5 for a graph of the data).

The data in Figure 6 demonstrates the participants' frequency and percentage distribution by the podiatry referral group. The green bars indicate the frequency and the red bars denote the percentage. As shown in Figure 6, 51 (38\%) participants answered: "Yes," and 84 (62\%) "No" (see Figure 6 for a graph of the data).

The data in Figure 7 illustrates the participants' frequency and percentage distribution by the type of diabetes group. Each participant was categorized as either T1DM or T2DM. The green bars indicate the frequency and the red bars displays the percentage. As shown in Figure 7, all the participants $(100 \%)$ have a diabetes type (see Figure 7 for a graph of the data).

The data in Figure 8 displays the participants' frequency and percentage distribution by pre diabetic foot exam completed group $(n=50)$. The green bars indicate the frequency and red 
bars indicate the percentage. As shown in Figure 8, 23 (46\%) participants answered: "Yes," and $27(54 \%)$ "No" (see Figure 8 for a graph of the data).

The data in Figure 9 illustrates the participants' frequency and percentage distribution by post diabetic foot exam completed group $(n=85)$. The green bars indicate the frequency and the red bars denote the percentage. As shown in Figure 9, 45 (53\%) participants answered: "Yes," and $40(47 \%)$ "No" (see Figure 9 for a graph of the data).

\section{Data Collection}

This evidence-based practice project began after receiving approval from the University of Saint Augustine for Health Sciences (USAHS) Evidence-Based Practice Review Committee and the facility's approval from the IRB. The project manager gained IRB approval before the project implementation to ensure patients' human rights protection. The project manager completed a checklist for reviewing privacy, confidentiality, and information security in research and all the necessary training on privacy and data use.

The hard copies of the patient data results were kept in a locked cabinet in the nurse manager's office when not in use to ensure information privacy. The electronic data collected was stored on an Excel spreadsheet and encrypted and password protected on the project manager's laptop, which was only accessible to her. The project manager adhered to strict confidentiality measures using the guidelines of the university's EPRC, the facility IRB, and the Belmont Report.

Retrospective pre intervention and post intervention chart reviews by the project manager was the method to gather information for this project. The quality manager team member assisted with the data retrieval from the VSSC's retroactive chart review of the patients in the 
PCCs before the project manager's intervention implementation. The project manager used the data to evaluate the observed outcomes following the intervention.

The project manager created a Microsoft Excel spreadsheet to input all data about the evidence-based practice project. This spreadsheet contained demographic data that consisted of descriptive information about the participants, such as the patient's age, gender, and diabetes type and whether a provider had performed a yearly foot exam. The pre intervention chart reviews in the EHR and the data attained from the VSSC provided the baseline data for this project. The project manager performed a chart audit and collected data before implementing the process change. The project manager recorded provider adherence to performing a foot exam in the Excel spreadsheet. Additional data collected and recorded in the spreadsheet included the type of provider, clinic location, and a podiatry referral. Participants' demographic characteristics — such as job classification, knowledge related to foot exam, and education — were also included (see the Excel spreadsheets in Appendix E and F).

The second part of the data collection involved a pre and post test assessment of provider and staff knowledge. The knowledge assessment questionnaire was an essential tool in determining a baseline for auditing, monitoring, and a way of reinforcing the knowledge needed to perform foot exams. The project manager collected the data 30 days before the intervention to establish the pre implementation comparison versus 30 days of post intervention data. The project manager collected data at weekly intervals. The project manager collected the pre and post test provider and staff knowledge assessments to determine the percent of providers and staff who had completed the questionnaire. The questionnaire consisted of a six-question pre and post-test provider questionnaire (see the pre and post test provider questionnaire in Appendix G and $\mathrm{H})$. 
The project manager administered the initial questionnaire before the initial audience training sessions. The charge nurse for the primary care clinics assisted the providers and staff with signing the record training sheet and distributing the staff's questionnaires. There was a low return rate of the questionnaires handed out by the charge nurse. Therefore, the project manager made weekly follow-up visits to the clinics to reinforce the education and training provided and also retrieved the missing questionnaires.

\section{Formative Evaluation}

Education and training programs were conducted by the designated clinic staff during weekly staff meetings and clinic huddles. The project manager trained the providers and staff on how to use Inlow's 60-Second Diabetic Foot Screening tool to perform a foot exam and how to perform a risk assessment. Permission to use this tool was requested by the project manager on July 3, 2020, and approved on July 6, 2020, by the Canadian Association of Wound Care. The project manager reviewed the foot exam and risk assessment tool to determine its accuracy and used it as a guide to train and educate the staff on how to perform a foot exam. Data collected from Inlow's 60-Second Diabetic Foot Screening Tool consisted of how to assess for skin and nail changes, loss of protective sensation, bony deformity, and risk (see Appendices I, J, and K). Each provider and staff received copies of this tool to assist in their routine foot assessment. There was a nominal return of Inlow's 60 Second Diabetic Screen Tool from the providers. Therefore, the project manager made weekly visits to the clinics to audit, monitor, and reinforce the staff and providers' instructional information.

After each education and training session, the project manager, or the designated clinic staff, secured a general-purpose training record. The training record included the date, name, 
staff/provider position, clinic location, and signature of the staff/provider who attended the weekly training sessions and huddles.

The project manager conducted a vast majority of the education and training sessions via WebEx video conferences and was facilitated by the diabetic foot specialist from the interprofessional team due to the limitations on large crowds with COVID-19 restrictions. There were obstacles to providing face-to-face training sessions for the target audience due to clinic staffing on specific days. Group training sessions comprised a maximum of three staff members in a room who stood six feet apart due to the COVID-19 guidelines and restrictions. The project manager performed weekly training and education sessions until all clinic staff had completed them. The project manager monitored compliance with the education and training sessions using the attendance on the WebEx video conference calls and the staff availability during face-to-face sessions in small groups.

\section{Summative Evaluation}

This evidence-based practice change project intends to evaluate provider adherence to perform an annual foot exam with the implementation of an ECR alert in T2DM. Therefore, the IT specialist created an ECR alert to remind providers to perform a diabetic foot exam. A knowledge assessment questionnaire designed by the project manager was also developed and used to evaluate the providers and the staff's pre and post intervention knowledge assessment.

\section{Data Analysis}

The project manager used a chi-squared test to determine the relationship between completing the exam and implementing the ECR alert. There was no statistical significance $\chi^{2}(1$, $\mathrm{N}=135)=.01, \mathrm{p}=.91$. The project manager performed a paired-samples t-test to compare the pre and post assessment of provider and staff knowledge after the implementation of the 
interventions. The pre assessment knowledge questionnaire results showed the calculated mean of 9.49 and standard deviation of 2.23 compared to the post assessment with a calculated mean of 11.33 and a standard deviation of 1.33. Based on this result, there was a difference in the knowledge assessment post implementation as shown in the results displayed in Table 2 .

\section{Missing Data}

Missing data can negatively impact the conclusions drawn from the data (Sylvia \& Terhaar, 2014). It can threaten project's validity, leading to unfounded results, and reducing the project's statistical accuracy, which may produce biased estimates and invalid conclusions (Kang, 2013). There was a potential threat of missing data from the chart audits 30 days before and after the intervention implementation. The project manager prevented missing data by recruiting a provider team member to assist with data collection, analysis, and storage.

\section{Sustainability}

The plan for sustainability for this evidence-based practice change project consisted of creating a CDSS tool in the EHR. The IT specialist and the project manager used this tool to send a reminder to the providers about performing a foot exam. The sustainability of the project depended on the percentage of provider adherence to a complete foot exam. The project manager implemented the continuous evaluation process of using the EPRP to monitor foot exam adherence to ensure that the providers met the benchmark of $85 \%$ or more and thus achieved sustainability. The continuous monitoring and measuring of results enabled the sustainability of change in practice. See Measures (Appendix L) for more information.

\section{Impact}

Improving the quality of care of patients with T2DM is a crucial component of reducing risks and preventing long-term complications such as foot ulcers (Williams et al., 2018). This 
project's primary outcome showed that the implementation of an ECR alert to remind primary care providers to perform an annual diabetic foot exam did not show a statistically significant difference between the pre and post intervention comparisons. The preliminary analysis of the data showed that 23 patients, a completion rate of $46 \%$, had their annual diabetic foot exam before the intervention implementation, and 45 patients, a completion rate of $56.25 \%$, had their yearly diabetic foot exam after the post intervention implementation of the ECR alert. The project manager used a chi-squared test to determine the relationship between the completion of the exam and implementation of the ECR alert. Although provider adherence to provide the diabetic foot exam increased after implementing the ECR alert, there was no statistical significance $\chi^{2}(1, \mathrm{~N}=135)=.01, \mathrm{p}=.91$. Hence, there was an increase of $25.9 \%$ rate of provider compliance in performing a foot exam in 30 days, indicating clinical significance.

The project manager encountered several limitations during this project. Due to time constraints, the project manager and the designated clinic staff reviewed only 50 charts during the pre intervention phase and an additional 85 charts during the post intervention phase. A total of 135 different patient charts were reviewed during this project by the project manager. Second, the project manager recognized that COVID-19 restrictions limited the practice change to less than initially planned due to conditions on face-to-face patient visits to primary care providers. Therefore, the project manager collaborated with the providers and staff to heighten their awareness of performing foot exams during unscheduled visits and through the virtual video connect (VVC) and inspecting the patient's feet during the implementation phase of the project.

The project manager was made aware of the increased risk of community exposure to COVID-19 as the reason for limited face to-face provider and patient appointments. Hence, the number of patients who were seen and foot exams that the providers performed was limited 
without face-to-face visits. Due to COVID 19, the regularly scheduled appointments were converted over by the scheduling clerks to a VVC or a telephone visit appointment. With the VVC appointment, the provider received the ECR alert but could not perform a hands-on foot exam; instead, a visual foot assessment by the provider. In contrast, with the telephone appointment, the provider assesses the foot symptoms by phone triage after the ECR alert to perform a foot exam, causing an additional limitation. Lastly, the project manager reduced the evidence-based practice change project time frame to 30 days due to time constraints. Although provider adherence was not statistically significant, an increase in the number of exams the providers completed indicted a clinically meaningful improvement in outcomes 30 days after the implementation of the ECR alert.

Routine foot exams are essential to reduce foot complications in diabetic patients (Ortegon et al., 2004). During this project, the project manager realized that foot complications in patients with T2DM require a multidisciplinary team approach. This approach is necessary to assist with the providers' and staff education and training to ensure a knowledge base and perform a foot exam and risk assessment for preventive care. Hence, the data collected from the secondary outcome of the provider and staff knowledge assessment revealed a clinically significant increase in the number of foot exams performed and the number of podiatry referrals after the post intervention knowledge assessment.

This project involved a pre intervention chart review of patients with T2DM and a post intervention implementation of an ECR alert to remind providers to perform a foot exam on their patients with T2DM. The project's impact lies in the potential to improve the quality of care for patients with T2DM through early detection and prevention of potential foot-related 
complications. The future implications of this project include the construction of a roadmap for improved care for T2DM patients in any clinic setting with the use of the ECR alert.

\section{Plans for Dissemination}

The development of a dissemination plan is an essential component of the quality improvement project process (Joshi et al., 2014). The project manager presented a PowerPoint presentation with the project findings results on a run chart to the leadership team during the Employee Town Hall meeting. Hessing (2015) defines a run chart as a graph that depicts how well the quality improvement process performs and identifies relevant trends. A run chart also displays the observed data in a time sequence and the quality improvement project (Institute for Healthcare Improvement, 2020). The project manager received feedback from the USAHS faculty and the project's preceptor before providing the project results' during the internal presentation.

The primary audience was the Pentad leadership and the departmental service chiefs. The secondary audience was the primary care providers, the nursing staff, and the ancillary clinic staff. The project manager shared the project's results with the Pentad leadership team during the daily morning report. The project findings' presentation was a concise PowerPoint with handouts for each attendee to disseminate within their departments after the presentation. The project manager presented the same presentation during the monthly Quality Safety Value Board meeting. During this meeting, the project manager identified opportunities for improvement, and specific actions were discussed, implemented, and continuously monitored. Senior leadership required all the departmental service chiefs to attend this meeting; thus, providing another opportunity for them to disseminate handouts within their respective departments. 
The project manager implemented the dissemination plan during team huddles,

performance improvement meetings, group diabetes education classes, and teleconference to the staff and patients located at the community-based outpatient primary care clinics. The project manager emailed electronic copies of the run chart results to the public relations representative to display on the electronic communication boards throughout the hospital. The project manager provided hard copies of the educational materials, questionnaires for the providers and staff. The project manager encouraged the continual use of the tools used to collect the data in the clinics' data for the sustainability of practice change. Open communication with the staff and the project manager led to the project improvements through the clinic's communication boards' displayed results.

Additionally, the results of the evidence-based practice change project will be disseminated by project manager externally by submitting a poster presentation at the Mississippi Board of Nursing Annual State Nurses' Conference for the 2021 annual meeting. Widespread dissemination will include presenting the evidence-based practice project for publication in the Federal Practitioner Journal. This monthly peer-reviewed clinical journal serves more than 35,000 healthcare providers working within the Department of Veterans Affairs, the Department of Defense, and the Public Health Service.

\section{Conclusion}

Diabetes is a severe condition that can lead to foot ulcers and other complications involving the lower extremities. Preventative care and education regarding proper foot care are essential in the process of early detection and treatment of potential foot complications. Although the implementation of an ECR alert was not statistically significant, the increase in provider adherence to performing a foot exam over 30 days indicates consequential clinical significance. 
Moreover, foot exams, foot care, foot health education, and an alert in the EHR to remind

providers to perform foot exams in people with diabetes can improve health outcomes for people with diabetes. 


\section{References}

Alford, D., Alexander, S., \& Barr, R. (2018). Optimization of clinical decision support tools for the care of older adults with diabetes mellitus type 2. Computers, Informatics, Nursing, 36(6), 259-264. https://doi.org/10.1097/CIN.0000000000000452

Allen, M. L., Van der Does, A. M., \& Gunst, C. (2016). Improving diabetic foot screening at a primary care clinic: A quality improvement project. African Journal of Primary Health Care \& Family Medicine, 8(1), e1-9. https://doi.org/10.4102/phcfm.v8i1.955

American Diabetes Association, (2020). Microvascular complications and foot care: Standards of medical care in diabetes - 2020. Diabetes Care, 43(Supplement 1), S135-S151. https://doi.org/10.2337/dc20-S011.

Backman, R., Bayliss, S., Moore, D., \& Litchfield, I. (2017). Clinical reminder alert fatigue in healthcare: A systematic literature review protocol using qualitative evidence. Systematic Reviews, 6(1), 1-6. https://doi.org/10.1186/s13643-017-0627-z

Boyle, A. (2020). VA steps up foot mat program to prevent diabetic foot amputations. U.S. Medicine the Voice of Federal Medicine. www.usmedicine.com/clinicaltopics/diabetes/va-steps-up-foot-mat-program-to-prevent-diabetic-foot-amputations/

Black, R., \& Stutler, E. (2018). The importance of actionable alerts: Reducing alert fatigue to improve clinical decision support. Health Management Technology, 39(4), 10-11. https//www.hcinnovationgroup.com/home/article/13010176/the-importance-ofactionable-alerts-reducing-alert-fatigue-to-improve-clinical-decision-support

Bus, S., Netten, J., Lavery, L., Monteiro-Soares, M., Rasmussen, A., Jubiz, Y., \& Price, P. (2016). IWGDF guidance on the prevention of foot ulcers in at-risk patients with 
diabetes. Diabetes Metabolism Research and Reviews, 32(Suppl.1), 16-24. https://doi.org/10.1002/dmrr.2696

Buschkoetter, K. L. M., Powell, W. \& Mazour, L. (2019). Implementation of a comprehensive diabetic foot exam protocol in rural primary care. Online Journal of Rural Nursing \& Health Care, 19(1), 43-63. https://doi.org/10.14574/ojrnhc.v19i1.560

Centers for Disease Control and Prevention. (2019). Diabetes data statistics. htttps://www.cdc.gov/diabetes/data/index.html

Centers for Disease Control and Prevention. (2020). National diabetes statistics report, 2020. http://www.cdc.gov/diabetes/data/statistics-report/index.html

Craig, A. B, Strauss, M. B., Daniller, A., \& Miller, S. S. (2014). Foot sensation testing in the patient with diabetes: Introduction of the quick \& easy assessment tool. Wounds: A Compendium of Clinical Research and Practice, 26(8), 221-231. https://www.woundsresearch.com/article/foot-sensation-testing-patient-diabetesintroduction-quick-easy-assessment-tool

Department of Veterans Affairs, (n. d.). Credentialing and privileging. http://www.va.gov Department of Veterans Affairs, (2015a). About the G. V. (Sonny) Montgomery VA Medical Center. https://www.jackson.va.gov/about/index.asp

Department of Veterans Affairs, (2015b). Ongoing professional practice evaluation and focused professional practice evaluations. https://www.va.gov/vhapublications/ViewPublication.asp?pub_ID=3120

Department of Veterans Affairs, (2017). Veterans Health Administration (VHA) publicationsdirective 1420. https://www.va.gov/vhapublicaitions/publications.cfm?Pub=1 
Dang, D., \& Dearholt, S. (2018). Johns Hopkins Nursing Evidence-Based Practice, Third Edition: Model and Guidelines: Vol. Third edition. Sigma Theta Tau International.

Edupuganti, S., Bushman, J., Maditz, R., Kaminoulu, P., \& Halalau, A. (2019). A quality improvement project to increase compliance with diabetes measures in an academic outpatient setting. Clinical Diabetes and Endocrinology, 1-13. https://doi.org/10.1186/s40842-019-0084-9

Elfil, M., \& Negida, A. (2017). Sampling methods in clinical research: An educational review. Emergency, 5(1). https://doi.org/10.22037/aaem.v5i1.177

Gervera, K., \& Graves, B. A. (2015). Integrating diabetes guidelines into a telehealth screening tool. Perspectives in Health Information Management, 12, $1 \mathrm{f}$. https://pubmed.ncbi.nlm.nih.gov/26396557

Goulding, V., \& Bale, S. (2019). Diabetic foot assessment: A service improvement project aimed at enhancing compliance. Wounds $U K, 15(5), 44-53$. https://www.wounds-uk.com/journals

Green-Morris, G. (2019). An evaluation of the effectiveness of foot care education in rural clinics. Journal of Diabetes and Metabolic Disorders, 18, 207-215. https://doi.org/10.1007/s40200-019-00407-0

Guyatt, G., Oxman, A. D., Aki, E. A., Kunz, R., Vist, G., Brozek, J., \& Schunemann, H. (2011). GRADE guidelines: 1. Introduction-GRADE evidence profiles and summary of findings tables. Journal of Clinical Epidemiology, 64(4), 383-394. https://doi.org/10.1016/j.jclinepi.2010.04.026

Harris, A. D., McGregor, J. C., Perencevinch, E. N., Furuno, J. P., Jingkun, Z., Peterson, D. E., \& Finkelstien (2006). The use and interpretation of quasi-experimental studies in medical 
informatics. Journal of American Medical Informatics, 13(1), 16-23.

https://doi.org/10.1197/jamia.M1749

Harris-Hayes, M., Schootman, M., Schootman, J. C., \& Hasting, M. K. (2020). The role of physical therapists in fighting the type 2 diabetes epidemic. Journal of Orthopaedic \& Sports Physical Therapy, 50(1), 5-16.

https://www.jospt.org/doi/10.2519/jospt.2020.9154

Hessing, T. (2015). Run chart: Creation, analysis, \& rules. https://www.sixsigmastudyguide.com

Hingorani, A., LaMuraglia, G., Henke, P., Meissner, M., Loretz, L., Zinszer, K., Driver, \& Murad, M. (2016). The management of diabetic foot: A clinical practice guideline by the Society of Vascular Surgery in collaboration with the American Podiatric Medical Association and the Society for Vascular Medicine. Journal of Vascular Surgery, 63(2), 3S-21S. https://doi.org/10.1016/j.jvs.2015.10.003

Indian Health Service. (2020). Diabetes standards of care \& clinical practice resources: Foot care. https://www.ihs.gov/diabetes/clinician-resources/soc/foot-care1/\#SECTION1

Institute for Healthcare Improvement. (2020). Run chart tool. www.ihi.org

Ivers, N., Jamtvedt, G., Flottorp, S., Young, J. M., Odgaard-Jensen, J., French, S. D., O’Brien, M. A., Johansen, M., Grimshaw, J., \& Oxman, A. D. (2012). Audit and feedback: Effects on professional practice and healthcare outcomes. The Cochrane Database of Systematic Reviews, 6, CD000259. https://doi.org/10.1002/14651858.CD000259.pub3

Jia, P., Zhang, L., Chen, J., Zhao, P., \& Zhang, M. (2016). The effects of clinical decision support systems on medication safety: An overview. PLoS ONE, 11(12), e0167683. https://doi.org/10.1371/journal.pone.0167683 
Joret, M., Osman, K., Dean, A., Cao, C., van der Werf, B., \& Bhamidipaty, V. (2019).

Multidisciplinary clinics reduce treatment costs and improve patient outcomes in diabetic foot disease. Journal of Vascular Surgery, 70(3), 806-814.

https://doi.org/10.1016/j.jvs.2018.11.032

Joshi, M. S., Ransom, E. R., Nash, D. B. \& Ransom, S. B. (2014). The healthcare quality book: Vision, strategy and tools ( $3^{\text {rd }}$ ed.). Chicago, IL: Health Administration Press.

Kang, H. (2013). The prevention and handling of missing data. Korean Journal of Anesthesiology, 64(5), 402-406. https://doi.org/10.4097/kjae.2013.64.5.402

Kadu, M. K., \& Stolee, P. (2015). Facilitators and barriers of implementing the chronic care modelin primary: A systematic review. BMC Family Practice, 16(1), 1-14. https://doi.org/10.1186/s12875-014-0219-0

Kaushal, R., Shojania, K. G., \& Bates, D. W. (2013). Effects of computerized physician order entry and clinical decision support system on medication safety: A systematic review. Archives of Internal Medicine, 163(12), 1409-1416.

doi:10.1001/archinte.163.12.1409

Kumar, A., \& Carmichael, K. A. (2020). Diabetic foot ulcers: Managing a common and costly complication. Consultant, 60(3), 85-86. doi:10.25270/con.2020.03.00004

Kumar, S., Woodward-Kron, R., Frank, O., Knieriemen, A., \& Lau, P. (2018). Patient-directed reminders to improve preventive care in general practice for patients with type 2 diabetes: A proof of concept. Australian Journal of General Practice, 47(6), 383-388. https://doi.org/10.31128/AJGP-10-17-4353

Kurowski, J. R., Nedkoff, L., Schoen, D. E., Knuiman, M., Norman, P. E., \& Briffa, T. G. (2015). Temporal trends in initial and recurrent lower extremity amputations in people 
with and without diabetes in Western Australia from 2000 to 2010. Diabetes Research and Clinical Practice, 108(2), 280-287. https://doi.org/10.1016/j.diabres.2015.02.008

Lewin, K. (1951). Field theory in social science. Harper and Row.

Lin, C. W., Armstrong, D. G., Lin, C. H., Liu, P. H., Hung, S. Y., Lee, S. R., Huang, C. H., Y Haung, Y. Y. (2019). Nationwide trends in the epidemiology of diabetic foot complications and lower extremity amputation over an 8-year period. BMJ Open Diabetes Research \& Care, 7(1), e000795. https://doi.org/10.1136/bmjdrc-2019-000795

Marcellus, L., Harrison, A., \& Mackinnon, K. (2012). Quality improvement for neonatal nurses, part II: Using a PDSA quality improvement cycle approach to implement an oral feeding progression guideline for premature infants. Neonatal Network, 31(4), 215-222. doi:10.1891/0730-0832.31.4.215

Maurer, E., Wallmeier, V., Reumann, M. K., Ehnert, S., Ihle, C., Schreiner, A. J., Flesch, I., Issack, P. S., Stollhof, L. E., \& Nussler, A. K. (2020). Risk of malnutrition in orthopedic trauma patients with surgical site infections is associated with increased morbidity and mortality - a 3-year follow-up study. Injury, 51(10), 2219-2229. https://doi.org/10.1016/j.injury.2020.06.019

McCoy, A. B., Thomas, E. J., Krousel-Wood, M., \& Sittig, D. F. (2014). Clinical decision support alert appropriateness: A review and proposal for improvement. The Ochsner Journal, 14(2), 195-292. www.pubmed.ncbi.nlm.nih.gov/24940129

Nteleki, B., \& Njokweni, M. (2015). Want to avoid DFUs? A multidisciplinary team approach works best. Journal of Wound Care, 24(5), 8-14. doi:10.12968/jowc.2015.24.sup5b.8

Nursing Theory. (2016). Lewin's change theory. http://nursing-theory.org/theories-andmodels/lewin-change-theory.php 
Nuti, L., Turkcan, A., Lawley, M. A., Zhang, L., Sands, L., \& McComb, S. (2015). The impact of interventions on appointment and clinical outcomes for individuals with diabetes: A systematic review. BMC Health Services Research, 15, 1-55. https://doi.org/10.1186/s12913-015-0938-5

Ortegon, M. M., Redekop, W. K., \& Niessan, L. W. (2004). Cost-effectiveness of prevention and reatment of the diabetic foot: A Markov analysis. Diabetes Care, 24(4), 901-907. https://doi.org/10.2337/diacare.27.4.901

Pemayun, T. G. D., Naibaho, R. M., Novitasari, D., Amin, N., \& Minuljo, T. T. (2015). Risk factors for lower extremity amputation in patients with diabetic foot ulcers: A hospitalbased case-control study. Diabetic Foot \& Ankle, 6(0), 1-12. https://doi.org/10.3402/dfa.v6.29629

Pocuis, J., Man-Hoi, S., Janci, M. M., \& Thompson, H. J. (2017). Exploring diabetic foot exam performance in a specialty clinic. Clinical Nursing Research, 26(1), 82-92. https://doi.org/10.1177/1054773815596699

Polonsky, W. H., Fisher, L., \& Hessler, D. (2018). The impact of non-severe hypoglycemia on quality of life in patient with type 2 diabetes. Journal of Diabetes and Its Complications, 32(4), 373-378. https://doi.org/10.1015/j.jdiacomp.2018.01.014

Quach, T. V., \& Goldschmidt, M. H. (2019). Amputation risk assessments for veterans with diabetes. Federal Practitioner for the Health Care Professionals of the VA, DoD, and PHS, 36(Suppl 7), S10-S15. https://pubmed.ncbi.nlm.nih.gov/31892784/

Schaper, N. C., Van Netten, J. J., Apelqvist, J., Lipsky, B. A., \& Bakker, K. (2017). Prevention and management of foot problems in diabetes: A summary guidance for daily practice 
2015, based on the IWGDF guidance documents. Diabetes Research and Clinical Practice, 124, 84-92. https://doi.org/10.1016/j.diabres.2016.12.007

Sculli, G. L. \& Hemphill, R. (2013). Culture of safety and just culture. VHA National Center for Safety. https://www.patientsafety.va.gov/docs/joe/just_culture_2013_tagged.pdf

Shelby, R. A., Dorfman, C. S., Arthur, S. S., Bosworth, H. B., Corsino, L, Sutton, L., Owen, L., Erkanli, A., Keefe, F., Corbett, C., \& Kimmick, G. (2020). Improving health engagement and lifestyle management for breast cancer survivors with diabetes. Contemporary Clinical Trials, 92, 1-10. https://doi.org/10.1016/j.cct.2020.105998

Shirey M. R. (2013). Lewin's theory of planned change as a strategic resource. Nursing Administration, 43(2), 69-72. doi:10.1097/NNA.0b013e31827f20a9

Smith-Dikes, V., \& Redd, D. L. (2014). G.V.(Sonny) Montgomery VA Medical Center. The American Legion: System Worth Saving Report. https://www.legion.org/sites/legion.org/files/legion/publications/SWS\%20Report\%20201 4\%20-\%20Jackson.pdf

Sylvia, M. L., \& Terhaar, M. F. (2014). An approach to clinical data management for the doctor of nursing practice curriculum. Journal of Professional Nursing, 30(1), 56-62. https://doi.org/10.1016/j.profnurs.2013.04.002

Tariq, G., \& Cruz, S. (2015). Don’t let diabetes mellitus knock you off your feet. World Council of Enterostomal Therapists Journal, 35(3), 14-35. www.wcetn.org

Vileikyte, L., Leventhal, H., Gonzalez, J. S., Peyrot, M., Rubin, R. R., Ulbrecht, J. S., Garrow, A., Waterman, C., Cavanagh, P. R., \& Boulton, A. J. M. (2005). Diabetic peripheral neuropathy and depressive symptoms: The association revisited. Diabetes Care, 28(10), 2378-2383. https://doi.org/10.2337/diacare.28.10.2378 
Vitale, M. Xu, C., Lou, W., Horodezny, S., Dorado, L., Sidani, S., Shah, B. R., \& Gucciardi, E. (2020). Impact of diabetes education teams in primary care on processes of care indicators. Primary Care Diabetes, 14(2), 111-118. https://doi.org/10.1016/j.pcd.2019.06.004

Wexler, D. J., Nathan, D. M., \& Mulder, J. (2020). Evaluation of the diabetic foot. https://www.uptodate.com/contents/evaluation-of-the-diabetic-foot

Williams, Y., Jones, S., \& Johnson, K. (2018). Increasing healthcare provider compliance in performing foot examinations in diabetic patients. Online Journal of Nursing Informatics, 22(3), 4-13. http://www.hims.org/ojni

World Health Organization. (2020). Diabetes. https://www.who.int/news-room/factsheets/detail/diabetes

Wrobel, J. S., Chagares, W., Stuck, R. M., Weaver, F., Crews, R. T., Rapacki, L., Paulson, R., \& Armstrong, D. G. (2011). Creating a diabetes foot reminder-based registry using the electronic medical record. Informatics in Primary Care, 18(4), 283-287. https://doi.org/10.14236/jhi.v18i4.783

Wu, S., Chan, K., Bae, J., \& Ford, E. (2019). Electronic clinical reminder and quality of primary diabetes care. Primary Care Diabetes, 13(2), 150-157. https://doi.org/10.1016/j.pcd.2018.08.007 


\section{Table 1}

Project Budget

\begin{tabular}{|c|r|l|r|}
\hline EXPENSES & & REVENUE & \\
\hline Direct & & Billing & NA \\
\hline Salary and benefits (IT, RNs, & $\$ 5,000$ & Grants & \\
\hline NAs, MDs, NPs) & & & \\
\hline Training supplies (pamphlets, & $\$ 1500$ & Institutional & \\
\hline blue pads, monofilaments) & & budget support & \\
\hline Services & & & \\
\hline Statistician & $\$ 200$ & & \\
\hline Staples, paper clips, cabinet & & & \\
\hline locks) & & & \\
\hline Ondirect & & & \\
\hline & & & \\
\hline Notal Expenses & & & \\
\hline & & & \\
\hline
\end{tabular}




\section{Table 2}

Pre and Post Implementation Paired Sample Statistics Provider and Staff Knowledge

\begin{tabular}{ccccccc}
\hline Variables & $N$ & Mean & $S D$ & $D f$ & t-value & $p$-value \\
\hline Pre Implementation & 55 & 9.49 & 2.23 & \multirow{2}{*}{4} & \multirow{2}{*}{4.731} & 0.000 \\
Post Implementation & 55 & 11.33 & 1.33 & & & \\
\hline
\end{tabular}

Note. Significant at the 0.05 level (2-tailed) 
Figure 1

Prisma Flow Diagram

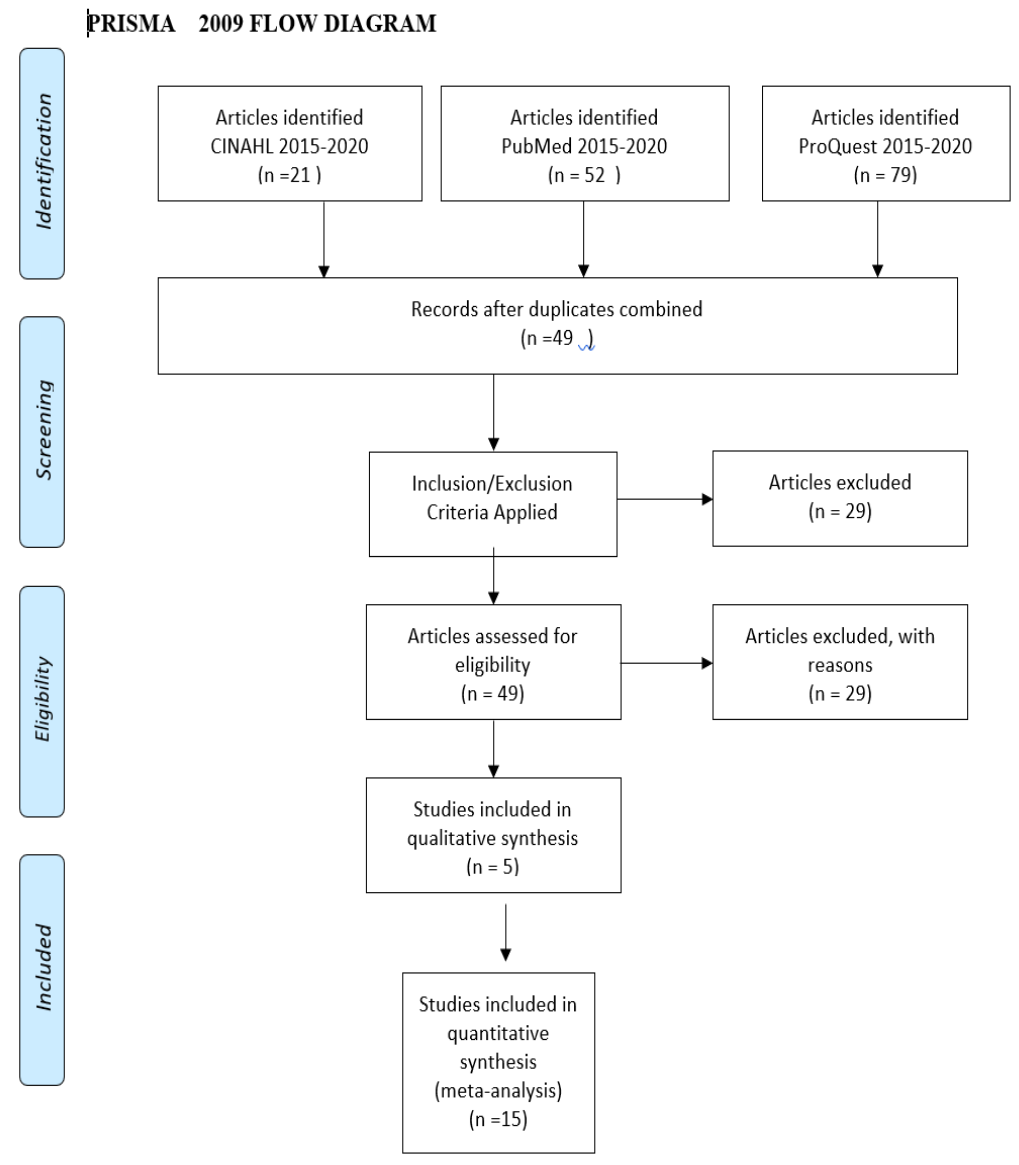


Figure 2

Participants' Age Distribution

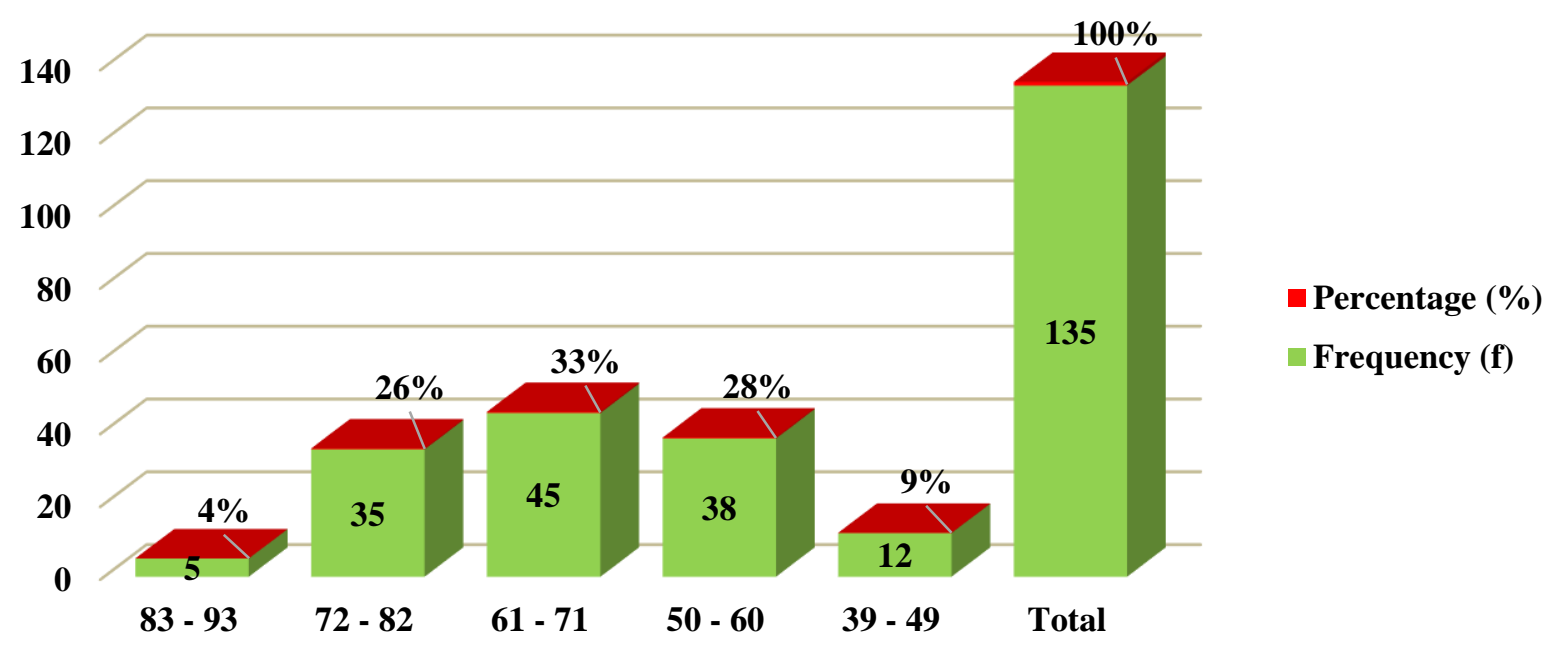

Note. This figure describes the frequency and percentage distribution of participants by age group. 
Figure 3

Gender Statistics

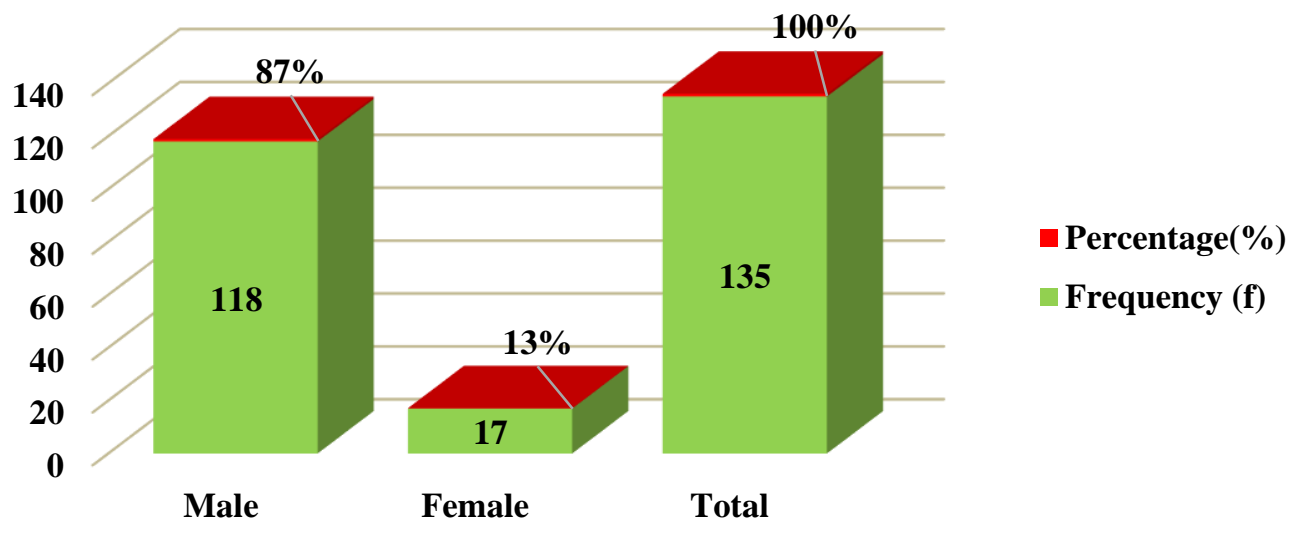

Note. This figure designates the frequency and percentage distribution of participants by gender group. 


\section{Figure 4}

\section{Clinic Group Participants}

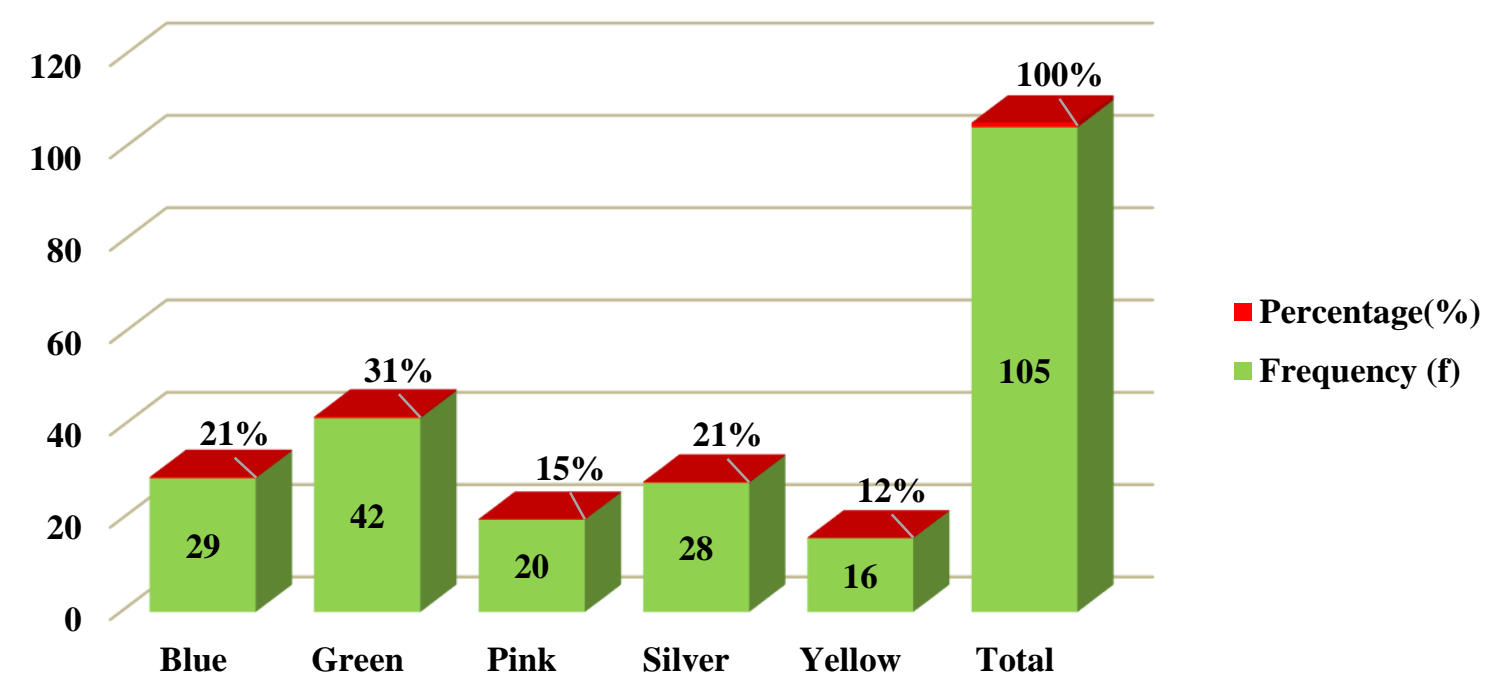

Note. This figure designates frequency and percentage distribution of participants by clinic group. 
Figure 5

Provider Group Participants

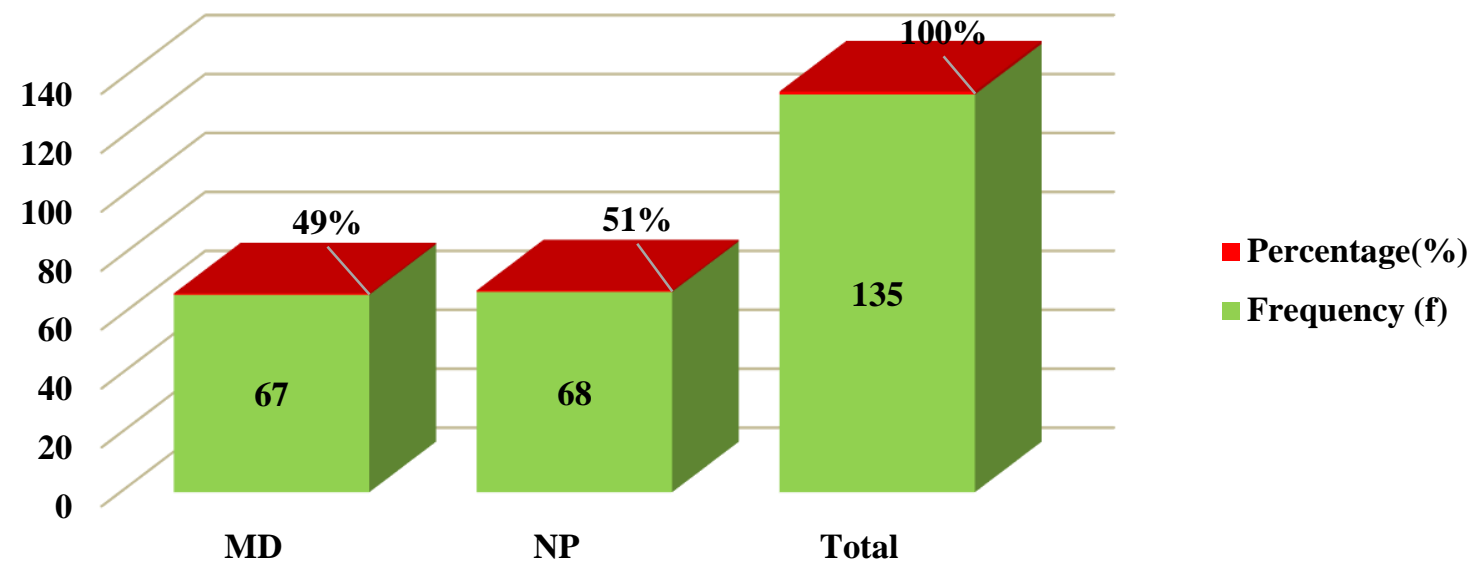

Note. This figure designates frequency and percentage distribution of participants by provider group. 


\section{Figure 6}

Podiatry Referrals

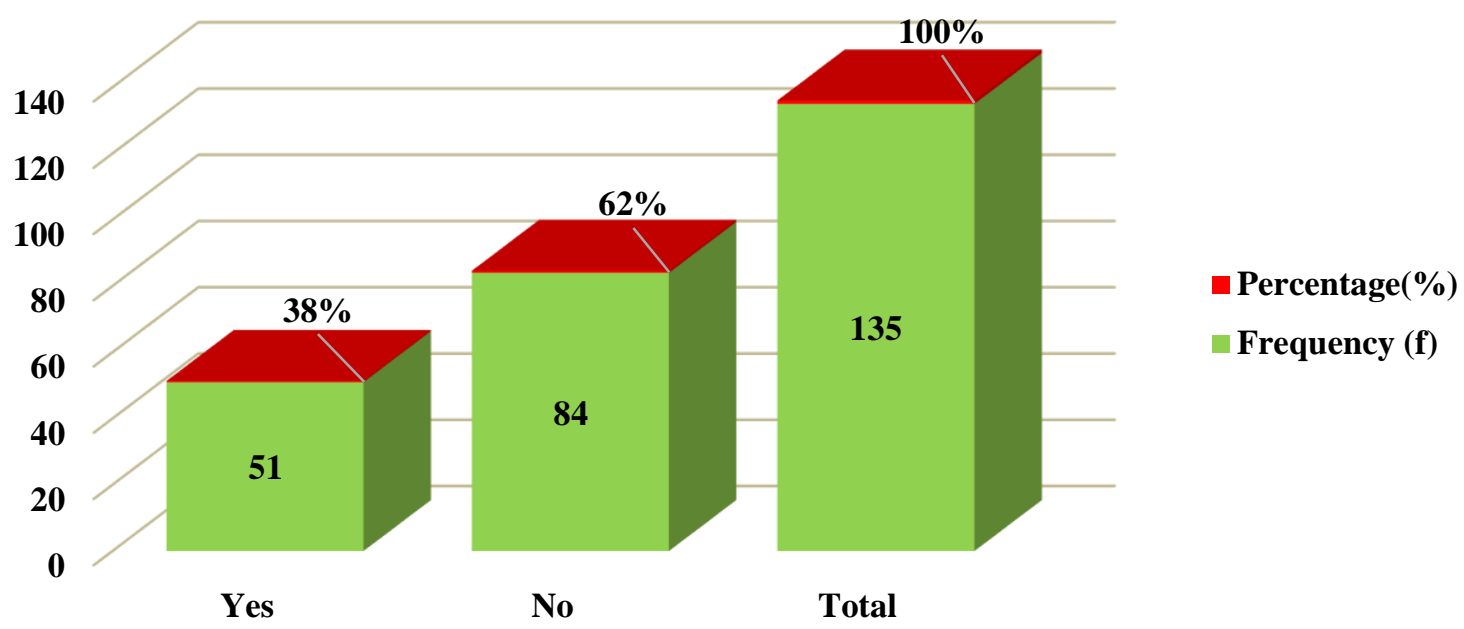

Note. This figure designates frequency and percentage distribution of participants by the Podiatry referral group. 


\section{Figure 7}

Type of Diabetes Group

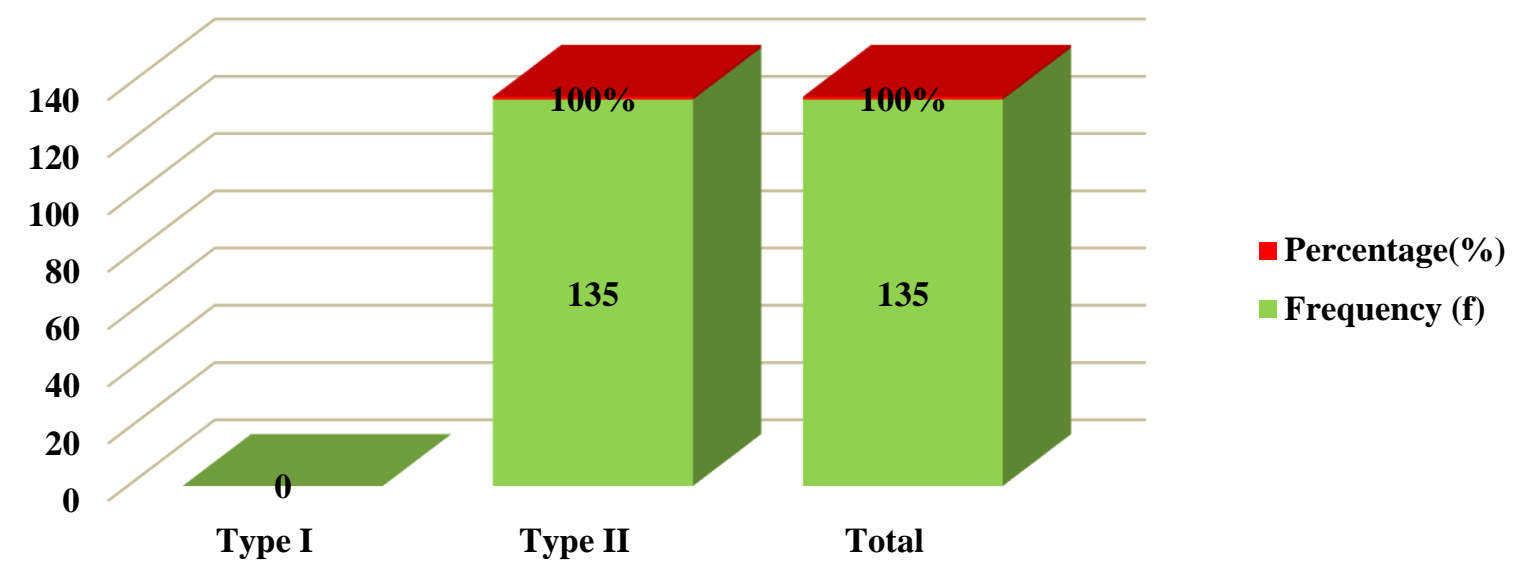

Note. This figure designates frequency and percentage distribution of participants by type of diabetes group. 


\section{Figure 8}

Pre Foot Exam Completion

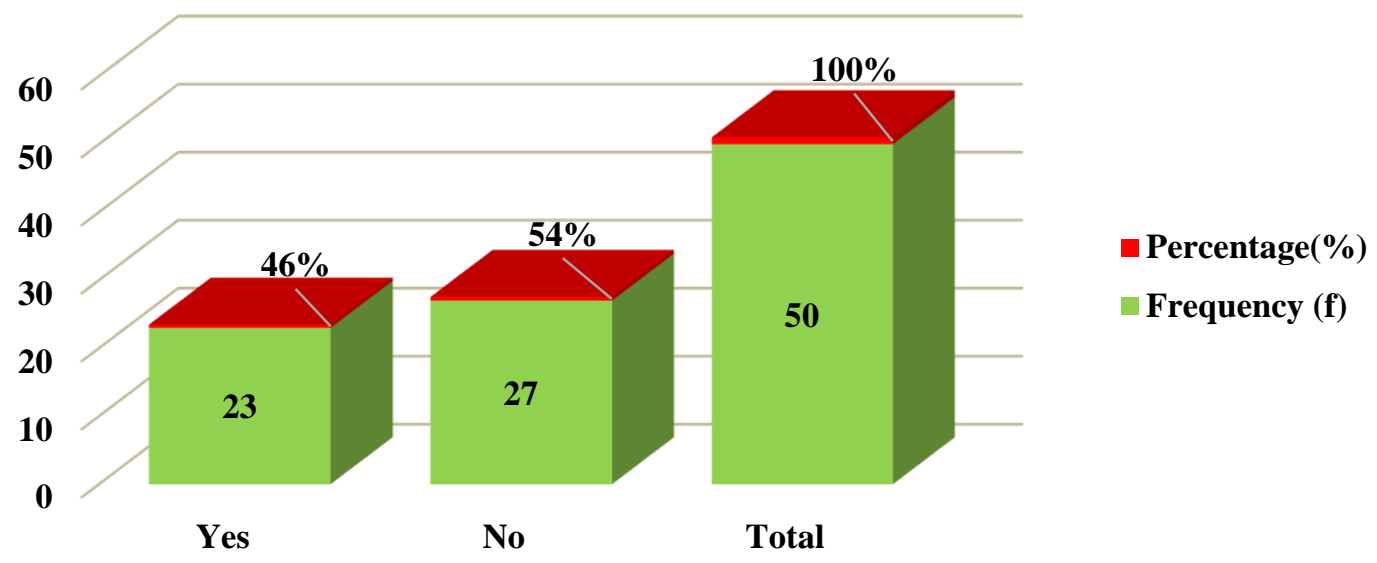

Note. This figure designates frequency and percentage distribution of participants by prediabetic foot exam completed group. 


\section{Figure 9}

Post Foot Exam Completion

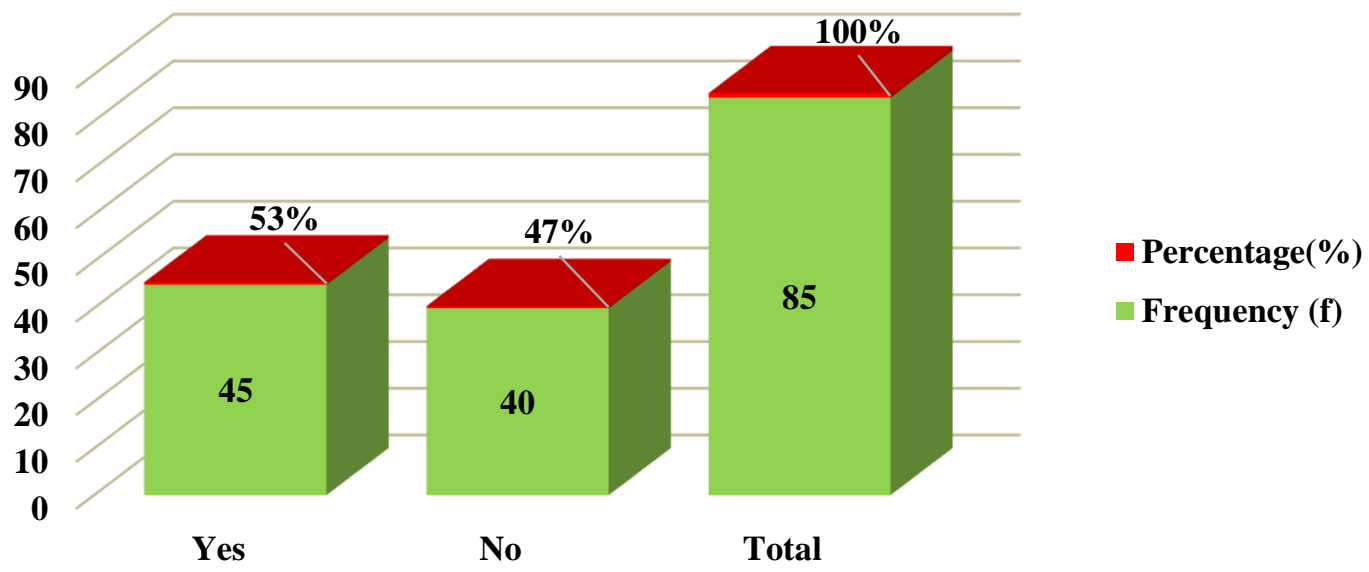

Note. This figure designates frequency and percentage distribution of participants by post diabetic foot exam completed group. 


\section{Appendix A}

\section{Main Ideas/Strengths of the Grading of Primary Evidence}

\begin{tabular}{|c|c|c|c|c|c|c|}
\hline Citation & $\begin{array}{l}\text { Design, } \\
\text { Level } \\
\text { Quality } \\
\text { Grade }\end{array}$ & $\begin{array}{l}\text { Sample } \\
\text { Sample } \\
\text { Size }\end{array}$ & $\begin{array}{l}\text { Intervention } \\
\text { Comparison } \\
\text { (Definitions } \\
\text { should include } \\
\text { any specific } \\
\text { research tools } \\
\text { used along } \\
\text { with reliability } \\
\text { and validity) }\end{array}$ & $\begin{array}{l}\text { Theoretical } \\
\text { Foundation }\end{array}$ & $\begin{array}{l}\text { Outcome } \\
\text { Definition }\end{array}$ & $\begin{array}{l}\text { Usefulness } \\
\text { Results } \\
\text { Key Findings }\end{array}$ \\
\hline $\begin{array}{l}\text { Alford, D., Alexander, S., \& } \\
\text { Barr, R. (2018). } \\
\text { Optimization of } \\
\text { clinical decision } \\
\text { support tools for the } \\
\text { care of older adults } \\
\text { with Diabetes } \\
\text { Mellitus Type } 2 . \\
\text { Computers, } \\
\text { Informatics, } \\
\text { Nursing, 36(6), } \\
\text { 259-264. } \\
\text { https://doi.org/10.10 } \\
\text { 97/CIN.000000000 } \\
\text { 0000452 }\end{array}$ & $\begin{array}{l}\text { Design: } \\
\text { Quantitativ } \\
\text { e } \\
\text { Level: V } \\
\text { Quality: } \\
\text { Good } \\
\text { Grade: B }\end{array}$ & $\begin{array}{l}\text { Sample } \\
\text { Size: } 104 \\
\text { Type } 2 \\
\text { Diabetic } \\
\text { Patients }\end{array}$ & $\begin{array}{l}\text { Clinical } \\
\text { Decision } \\
\text { Support System } \\
\text { (CDSS) Tool; } \\
\text { The ADA } \\
\text { updated } \\
\text { Standards of } \\
\text { Medical Care in } \\
\text { Diabetes } 2017 .\end{array}$ & $\begin{array}{l}\text { Rogers' } \\
\text { diffusion of } \\
\text { innovations } \\
\text { theory } \\
\text { includes } \\
\text { invention, } \\
\text { diffusion, } \\
\text { time, and } \\
\text { consequenc } \\
\text { es (Rogers, } \\
\text { 1983). }\end{array}$ & $\begin{array}{l}\text { To obtain data } \\
\text { from healthcare } \\
\text { providers } \\
\text { regarding the } \\
\text { efficiency of the } \\
\text { CDSS tools } \\
\text { used; } \\
\text { To quantify the } \\
\text { current state of } \\
\text { care for adults } \\
\text { with DM Type } 2 \\
\text { using guidelines } \\
\text { and data from } \\
\text { electronic health } \\
\text { records (Alford } \\
\text { et al., 2018). }\end{array}$ & $\begin{array}{l}\text { The project optimized } \\
\text { existing CDSS to provide } \\
\text { preventive and follow-up } \\
\text { care reminders to patients; } \\
\text { Standardized clinical } \\
\text { practice guidelines to help } \\
\text { guide treatment decisions } \\
\text { related to foot care by } \\
\text { reminding providers to } \\
\text { perform exams. }\end{array}$ \\
\hline $\begin{array}{l}\text { Allen, M. L., van der Does, A. } \\
\text { M., \& Gunst, C. } \\
\text { (2016). Improving } \\
\text { Diabetic foot } \\
\text { screening at a } \\
\text { primary care clinic: } \\
\text { A quality } \\
\text { improvement } \\
\text { project. African } \\
\text { Journal of Primary } \\
\text { Health Care \& } \\
\text { Family Medicine, } \\
\end{array}$ & $\begin{array}{l}\text { Design: } \\
\text { Quality } \\
\text { Improvem } \\
\text { ent Cycle } \\
\text { Level: V } \\
\text { Quality: } \\
\text { Good } \\
\text { Grade: B }\end{array}$ & $\begin{array}{l}\text { Sample } \\
\text { Size: } 32 \\
\text { folders } \\
\text { audited. A } \\
\text { convenien } \\
\text { ce sample } \\
\text { of the } \\
\text { clinic } \\
\text { staff. }\end{array}$ & $\begin{array}{l}\text { Standards for } \\
\text { QUality } \\
\text { Improvement } \\
\text { Reporting } \\
\text { Excellence } \\
\text { (SQUIRE) }\end{array}$ & $\begin{array}{l}\text { Standards } \\
\text { for QUality } \\
\text { Improveme } \\
\text { nt } \\
\text { Reporting } \\
\text { Excellence } \\
\text { (SQUIRE) } \\
\text { quality } \\
\text { improveme } \\
\text { nt } \\
\text { framework }\end{array}$ & $\begin{array}{l}\text { To educate } \\
\text { clinic staff to } \\
\text { increase diabetic } \\
\text { foot screening } \\
\text { practices }\end{array}$ & $\begin{array}{l}\text { Staff education is an } \\
\text { essential component in foot } \\
\text { exam compliance and } \\
\text { outcomes. }\end{array}$ \\
\hline
\end{tabular}




\begin{tabular}{|c|c|c|c|c|c|c|}
\hline $\begin{array}{l}\text { 8(1), e1-e9. } \\
\text { https://doi.org/10.41 } \\
\text { 02/phcfm.v811.955 }\end{array}$ & & & & & & \\
\hline $\begin{array}{l}\text { Buschkoetter, K., Powell, W., } \\
\text { \& Mazour, L. } \\
\text { (2019). } \\
\text { Implementation of a } \\
\text { comprehensive } \\
\text { diabetic foot exam } \\
\text { protocol in a rural } \\
\text { primary care. } \\
\text { Online Journal of } \\
\text { Rural Nursing and } \\
\text { Health Care, 19(1). } \\
\text { https://doi.org/10.14 } \\
\text { 74/0jrnhc.v19il.560 }\end{array}$ & $\begin{array}{l}\text { Design: } \\
\text { Quantitative } \\
\text { Retrospectiv } \\
\text { Chart Reviey } \\
\text { Level: III } \\
\text { Quality: B } \\
\text { Grade: Good }\end{array}$ & $\begin{array}{l}\text { Sample } \\
\text { Size: } 60 \\
\text { charts }\end{array}$ & $\begin{array}{l}\text { Comprehensive } \\
\text { Foot Exam } \\
\text { (CFE) and Risk } \\
\text { Assessment } \\
\text { Michigan } \\
\text { Neuropathy } \\
\text { Screen } \\
\text { Instrument } \\
\text { (MNSI) is a } \\
\text { valid measure } \\
\text { of distal } \\
\text { peripheral } \\
\text { neuropathy in } \\
\text { patient } \\
\text { (Herman, et al., } \\
\text { 2012). }\end{array}$ & $\begin{array}{l}\text { Health } \\
\text { Belief } \\
\text { Model and } \\
\text { Awareness } \\
\text { to } \\
\text { Adherence } \\
\text { Model }\end{array}$ & $\begin{array}{l}\text { To increase PCP } \\
\text { and office } \\
\text { nursing staff } \\
\text { knowledge of } \\
\text { BP guidelines } \\
\text { for CFE 50/80 or } \\
63 \% \text { of patients } \\
\text { with T2DM; } \\
\text { CFE performed } \\
\text { and documented } \\
63 \% \text { adult } \\
\text { patients with } \\
\text { T2DM; } \\
\text { RA performed } \\
\text { and documented } \\
\text { in } 63 \% \\
\text { compliance in } \\
15 \text { weeks. }\end{array}$ & $\begin{array}{l}\text { Three out of four Rural } \\
\text { Health Clinics showed } \\
\text { improved \% of completion } \\
\text { of CFE; } \\
\text { Five out of six PCPs'\% of } \\
\text { completion of foot exam } \\
\text { improved. }\end{array}$ \\
\hline $\begin{array}{l}\text { Edupuganti, S., Bushman, J., } \\
\text { Maditz, R., } \\
\text { Kaminoulu, P., \& } \\
\text { Halalau, A. (2019). } \\
\text { A quality } \\
\text { improvement } \\
\text { project to increase } \\
\text { compliance with } \\
\text { diabetes measures } \\
\text { in an academic } \\
\text { outpatient setting. } \\
\text { Clinical Diabetes } \\
\text { and Endocrinology, } \\
\text { 1. } \\
\text { https://doi.org/10.11 } \\
\text { 86/s40842-019- } \\
\text { 0084-9 }\end{array}$ & $\begin{array}{l}\text { Design: } \\
\text { Quasi- } \\
\text { experimental } \\
\text { Level: } 5 \\
\text { Quality: } \\
\text { Good } \\
\text { Grade: B }\end{array}$ & $\begin{array}{l}\text { Sample } \\
\text { Size: } \\
538 \\
\text { diabetic } \\
\text { patients }\end{array}$ & $\begin{array}{l}\text { Diabetic clinic } \\
\text { visit template } \\
\text { based on the } \\
\text { ADA clinical } \\
\text { practice } \\
\text { guidelines was } \\
\text { placed in the } \\
\text { EHR in a } 1 / 2 \\
\text { page reminder. }\end{array}$ & $\begin{array}{l}\text { Plan-Do-S. } \\
\text { tudy-Act } \\
\text { (PDSA) } \\
\text { framework } \\
\text { outlined by } \\
\text { the IHI }\end{array}$ & $\begin{array}{l}\text { To increase } \\
\text { provider } \\
\text { adherence in } \\
\text { performing foot } \\
\text { exam along with } \\
\text { other ADA } \\
\text { guidelines for } \\
\text { clinical practice } \\
\text { for the diabetic } \\
\text { patient by } \\
\text { creating a } \\
\text { reminder for the } \\
\text { residents' } \\
\text { providers }\end{array}$ & $\begin{array}{l}\text { Intervention along with } \\
\text { ADA guideline of clinical } \\
\text { practice show that there was } \\
\text { improvement in } \\
\text { preventative care for patient } \\
\text { with diabetes in resident } \\
\text { clinics. }\end{array}$ \\
\hline
\end{tabular}




\begin{tabular}{|c|c|c|c|c|c|c|}
\hline $\begin{array}{l}\text { Goulding, V., \& Bale, S. } \\
\text { (2019). Diabetic } \\
\text { foot assessment: A } \\
\text { service } \\
\text { improvement } \\
\text { project aimed at } \\
\text { enhancing } \\
\text { compliance. } \\
\text { Wounds UK, 15(5), } \\
\text { 44-53. } \\
\text { https://scholar.googl } \\
\text { e.com/scholar?h1=e } \\
\text { n\&as }\end{array}$ & $\begin{array}{l}\text { Design: } \\
\text { Quantitativ } \\
\text { e } \\
\text { Chart } \\
\text { Audits } \\
\text { Level: II } \\
\text { Quality: } \\
\text { Good } \\
\text { Grade: B }\end{array}$ & $\begin{array}{l}\text { Sample } \\
\text { Size: } \\
33\end{array}$ & $\begin{array}{l}\text { Foot Protection } \\
\text { Tool (FPT). } \\
\text { The validity } \\
\text { was not tested } \\
\text { in the pilot } \\
\text { study but the } \\
\text { inter-rater } \\
\text { reliability was } \\
\text { high (Goulding } \\
\text { \& Bale, 2019); } \\
\text { The use of the } \\
\text { National } \\
\text { Diabetes } \\
\text { Inpatient Audit } \\
\text { (NaDIA) form } \\
\text { strengthened } \\
\text { validity and } \\
\text { reliability of } \\
\text { this study } \\
\text { (Goulding \& } \\
\text { Bale, 2019) } \\
\text { NICE. }\end{array}$ & $\begin{array}{l}\text { None } \\
\text { clearly } \\
\text { stated }\end{array}$ & $\begin{array}{l}\text { To improve } \\
\text { compliance with } \\
\text { the NICE NG19 } \\
\text { (2016) } \\
\text { guidelines for } \\
\text { the effective } \\
\text { implementation } \\
\text { of a diabetic foot } \\
\text { assessment } \\
\text { (DFA) tool. }\end{array}$ & $\begin{array}{l}\text { Improvement in the number } \\
\text { of DFA performed }\end{array}$ \\
\hline $\begin{array}{l}\text { Green-Morris, G. (2019). An } \\
\text { evaluation of the } \\
\text { effectiveness of foot } \\
\text { care education in } \\
\text { rural clinics. } \\
\text { Journal of Diabetes } \\
\text { and Metabolic } \\
\text { Disorders. } \\
\text { https://doi.org/10.10 } \\
\text { 07/s40200-019- } \\
\text { 99497-0 }\end{array}$ & $\begin{array}{l}\text { Design: } \\
\text { Quantitativ } \\
\text { e } \\
\text { Descriptiv } \\
\text { e Statistics } \\
\text { Level: III } \\
\text { Quality: } \\
\text { Low } \\
\text { Grade: C }\end{array}$ & $\begin{array}{l}\text { Convenie } \\
\text { nce } \\
\text { sample of } \\
9 \text { pre and } \\
\text { postinterv } \\
\text { ention } \\
\text { questionn } \\
\text { aires and } \\
\text { a } \\
\text { convenien } \\
\text { ce sample } \\
\text { of } 4 \text { clinic } \\
\text { nurses } \\
\text { completed } \\
\text { a } \\
\text { preinterve } \\
\text { ntion } \\
\text { questionn } \\
\text { aire }\end{array}$ & $\begin{array}{l}\text { Verbal and } \\
\text { Visual } \\
\text { education tools } \\
\text { to improve the } \\
\text { acquisition of } \\
\text { knowledge and } \\
\text { measure the } \\
\text { effectiveness of } \\
\text { knowledge. } \\
\text { The } \\
\text { interventions } \\
\text { were Patient } \\
\text { Interpretation } \\
\text { of Neuropathy } \\
\text { (PIN) } \\
\text { and Diabetes } \\
\text { Attitude Scale } \\
\text { (DAS-3). }\end{array}$ & $\begin{array}{l}\text { Knowles' } \\
\text { adult } \\
\text { learning } \\
\text { theory; } \\
\text { Orem's } \\
\text { self-care } \\
\text { context; the } \\
\text { input, } \\
\text { process and } \\
\text { product } \\
\text { (CIPP) } \\
\text { model. }\end{array}$ & $\begin{array}{l}\text { To evaluate the } \\
\text { effectiveness of } \\
\text { the program; } \\
\text { To record the } \\
\text { participants' } \\
\text { perception of } \\
\text { their } \\
\text { experiences; } \\
\text { To analyze the } \\
\text { demographic } \\
\text { data and } \\
\text { knowledge } \\
\text { retained. }\end{array}$ & $\begin{array}{l}\text { Increase in the amount of } \\
\text { knowledge obtained from } \\
\text { the education provided; } \\
\text { Diabetic patients' lack of } \\
\text { knowledge of foot care. }\end{array}$ \\
\hline $\begin{array}{l}\text { Kumar, S., Woodward-Kron, } \\
\text { R., Frank, O., } \\
\text { Knieriemen, A., \& } \\
\text { Lau, P. (2018). }\end{array}$ & $\begin{array}{l}\text { Design: } \\
\text { Mixed } \\
\text { Method }\end{array}$ & $\begin{array}{l}\text { Sample } \\
\text { Size: } \\
\text { Convenie } \\
\text { nce }\end{array}$ & $\begin{array}{l}\text { Doctors Control } \\
\text { Panel (DCP) } \\
\text { software tool; }\end{array}$ & $\begin{array}{l}\text { Not clearly } \\
\text { defined }\end{array}$ & $\begin{array}{l}\text { To evaluate } \\
\text { whether } \\
\text { implementation } \\
\text { of the }\end{array}$ & $\begin{array}{l}\text { The reminder strategy } \\
\text { improved quality of chronic } \\
\text { disease care delivered in a } \\
\text { general practice; }\end{array}$ \\
\hline
\end{tabular}




\begin{tabular}{|c|c|c|c|c|c|c|}
\hline $\begin{array}{l}\text { Patient-oriented } \\
\text { reminders to } \\
\text { improve } \\
\text { preventive care in } \\
\text { general practice } \\
\text { for patients with } \\
\text { type } 2 \text { diabetes: A } \\
\text { proof of concept. } \\
\text { The Royal } \\
\text { Australian College } \\
\text { of General } \\
\text { Practitioners, } \\
\text { 47(6), 383-388. } \\
\text { https://doi.org/10.31 } \\
\text { 128/AJGP-10-17- } \\
\text { 4352 }\end{array}$ & $\begin{array}{l}\text { Quantitativ } \\
\text { e/ } \\
\text { Qualitative } \\
\text { Level: I } \\
\text { Quality: } \\
\text { High } \\
\text { Grade: A }\end{array}$ & $\begin{array}{l}\text { sampling } \\
\text { of } 4 \text { GPs } \\
\text { from a } \\
\text { general } \\
\text { practice } \\
\text { clinic; } \\
330 \\
\text { patients } \\
\text { from the } \\
\text { GP } \\
\text { clinics. }\end{array}$ & $\begin{array}{l}\text { Preconsultation } \\
\text { Preventive } \\
\text { Summary and } \\
\text { Reminder } \\
\text { System } \\
\text { (PPSRS) } \\
\text { downloaded } \\
\text { into the } \\
\text { electronic } \\
\text { health record } \\
\text { system to query } \\
\text { patients with } \\
\text { T2DM. }\end{array}$ & & $\begin{array}{l}\text { intervention } \\
\text { would have an } \\
\text { impact on } \\
\text { preventive care } \\
\text { in T2DM } \\
\text { patients }\end{array}$ & $\begin{array}{l}\text { Patient-directed reminders } \\
\text { improved the performance } \\
\text { of T2DM preventive care; } \\
\text { The PPSRS tool was } \\
\text { effective in preventive care } \\
\text { of T2DM in general } \\
\text { practice. }\end{array}$ \\
\hline $\begin{array}{l}\text { McCoy, A., Thomas, E., } \\
\text { Krousel-Wood, M., } \\
\text { \& Sittig, D. (2014). } \\
\text { Clinical decision } \\
\text { support alert } \\
\text { appropriateness: A } \\
\text { review and proposal } \\
\text { for improvement. } \\
\text { The Ochsner } \\
\text { Journal, 14(2), } \\
\text { 195-203. } \\
\text { www.pubmed.ncbi. } \\
\text { nlm.nih.gov/249401 } \\
\text { 29 }\end{array}$ & $\begin{array}{l}\text { Design: } \\
\text { Level: } 5 \\
\text { Quality: } \\
\text { Good } \\
\text { Grade: B }\end{array}$ & $\begin{array}{l}\text { Sample } \\
\text { Size: }\end{array}$ & $\begin{array}{l}\text { Alert evaluation } \\
\text { framework }\end{array}$ & $\begin{array}{l}\text { Duke and } \\
\text { Bolchini's } \\
\text { model for } \\
\text { creating } \\
\text { context- } \\
\text { awareness }\end{array}$ & $\begin{array}{l}\text { To prompt } \\
\text { providers to } \\
\text { manage patient } \\
\text { care needs }\end{array}$ & $\begin{array}{l}\text { Web-based monitoring tools } \\
\text { with an interactive } \\
\text { dashboard for evaluating } \\
\text { CDS alert and response } \\
\text { appropriateness }\end{array}$ \\
\hline $\begin{array}{l}\text { Quach \& Goldschmidt (2019). } \\
\text { Amputation risk } \\
\text { assessments for } \\
\text { veterans with } \\
\text { diabetes. Federal } \\
\text { Practitioner for the } \\
\text { Health Care } \\
\text { Professionals of the } \\
\text { VA, DoD, and } P H S, \\
\text { 36(Suppl 7), S10- } \\
\text { S15. } \\
\text { https://scholar.googl } \\
\text { e.com/scholar?hl=e } \\
\text { n\&as }\end{array}$ & $\begin{array}{l}\text { Design: } \\
\text { Quantitativ } \\
\text { e } \\
\text { Level: III } \\
\text { Quality: } \\
\text { High } \\
\text { Grade: A }\end{array}$ & $\begin{array}{l}\text { Sample } \\
\text { Size: } 191 \\
\text { appropriat } \\
\text { ely } \\
\text { completed } \\
\text { foot } \\
\text { exams }\end{array}$ & $\begin{array}{l}\text { Templated } \\
\text { electronic } \\
\text { health record } \\
\text { note in the } \\
\text { Computerized } \\
\text { Patient Record } \\
\text { System (CPRS) } \\
\text { Amputation } \\
\text { Risk } \\
\text { Assessment } \\
\text { Tool }\end{array}$ & $\begin{array}{l}\text { None } \\
\text { clearly } \\
\text { stated }\end{array}$ & $\begin{array}{l}\text { To evaluate } \\
\text { changes in the } \\
\text { number of } \\
\text { diabetic foot } \\
\text { exams and } \\
\text { amputation risk } \\
\text { assessments } \\
\text { completed for } \\
\text { veterans having } \\
\text { diabetes; } \\
\text { To evaluate the } \\
\text { number and } \\
\text { timeliness of } \\
\text { appropriate }\end{array}$ & $\begin{array}{l}\text { The quality-driven process } \\
\text { change improved the } \\
\text { documentation process to } \\
\text { reflect nationally accepted } \\
\text { standards; } \\
\text { Increased the number of } \\
\text { appropriate podiatry } \\
\text { referrals for the patients } \\
\text { classified as having } \\
\text { moderate-to-high risk of } \\
\text { developing foot ulcers. }\end{array}$ \\
\hline
\end{tabular}




\begin{tabular}{|l|l|l|l|l|l|}
\hline & & & & & $\begin{array}{l}\text { referrals to } \\
\text { podiatry for an } \\
\text { in-depth } \\
\text { assessment and } \\
\text { treatment of } \\
\text { veterans found } \\
\text { to be at } \\
\text { moderate-to- } \\
\text { high risk for } \\
\text { lower limb } \\
\text { amputations. }\end{array}$ \\
\hline
\end{tabular}

\begin{tabular}{|c|c|c|c|c|c|c|}
\hline Citation & $\begin{array}{l}\text { Design, } \\
\text { Level } \\
\text { Quality } \\
\text { Grade }\end{array}$ & $\begin{array}{l}\text { Sample } \\
\text { Sample size }\end{array}$ & $\begin{array}{l}\text { Intervention } \\
\text { Comparison } \\
\text { (Definitions } \\
\text { should include } \\
\text { any specific } \\
\text { research tools } \\
\text { used along with } \\
\text { reliability and } \\
\text { validity) }\end{array}$ & $\begin{array}{l}\text { Theoretical } \\
\text { Foundation }\end{array}$ & $\begin{array}{l}\text { Outcome } \\
\text { Definition }\end{array}$ & $\begin{array}{l}\text { Usefulness } \\
\text { Results } \\
\text { Key Findings }\end{array}$ \\
\hline $\begin{array}{l}\text { Pocuis, J., Man-Hoi, S., Janci, M. } \\
\text { M., \& Thompson, H. J. } \\
\text { (2017). Exploring } \\
\text { diabetic foot exam } \\
\text { performance in a } \\
\text { specialty clinic. Clinical } \\
\text { Nursing Research, } 1,82 . \\
\text { https://doi.org/10.1177/10 } \\
\text { 54773815596699 }\end{array}$ & $\begin{array}{l}\text { Design: } \\
\text { Quantitative } \\
\text { Cross } \\
\text { Sectional } \\
\text { survey } \\
\text { design along } \\
\text { with a } \\
\text { retrospectiv } \\
\text { e chart } \\
\text { review } \\
\text { Level: III } \\
\text { Quality: } \\
\text { Good } \\
\text { Grade: B } \\
\end{array}$ & $\begin{array}{l}\text { Sample } \\
\text { Size: } 100 \\
\text { patients } \\
\text { initially. } \\
\text { Twelve } \\
\text { were } \\
\text { excluded } \\
\text { and the } \\
\text { study } \\
\text { continued } \\
\text { with } 88 \\
\text { patients in } \\
\text { total. }\end{array}$ & $\begin{array}{l}\text { Diabetic Foot } \\
\text { Ulcer Health } \\
\text { Belief Scale } \\
\text { Validity reviewed } \\
\text { by a Certified } \\
\text { Diabetes } \\
\text { Educator/Family } \\
\text { Nurse Practitioner }\end{array}$ & $\begin{array}{l}\text { The Health } \\
\text { Belief Model; } \\
\text { The Health } \\
\text { Literacy } \\
\text { Model. }\end{array}$ & $\begin{array}{l}\text { To prevent the } \\
\text { incidence of foot } \\
\text { ulcers and } \\
\text { amputations rates by } \\
\text { performing foot } \\
\text { exams }\end{array}$ & $\begin{array}{l}\text { Future studies should include all } \\
\text { provider visits to patients which } \\
\text { would support meaningful use } \\
\text { through the measurement and } \\
\text { reporting of clinical quality } \\
\text { measures of diabetes care. }\end{array}$ \\
\hline $\begin{array}{l}\text { Tariq, G., \& Cruz, S. (2015). Don't } \\
\text { let diabetes mellitus } \\
\text { knock you off your feet. } \\
\text { World Council of } \\
\text { Enterostomal Therapists } \\
\text { Journal, 35(3), 14-35. }\end{array}$ & $\begin{array}{l}\text { Design: } \\
\text { Quantitative } \\
\text { Level: V } \\
\text { Quality: } \\
\text { Good } \\
\text { Grade: B }\end{array}$ & $\begin{array}{l}\text { Sample } \\
\text { Size: } 400 \\
\text { patients }\end{array}$ & $\begin{array}{l}60 \text { seconds } \\
\text { screening tool; } \\
\text { Final root causes } \\
\text { were validated by } \\
\text { using code and } \\
\text { cross-reference }\end{array}$ & $\begin{array}{l}\text { None clearly } \\
\text { stated }\end{array}$ & $\begin{array}{l}\text { To achieve at least } \\
95 \% \text { compliance of } \\
\text { staff in ensuring } \\
\text { wound care } \\
\text { consultation orders } \\
\text { for patients who are } \\
\text { assessed as being at }\end{array}$ & $\begin{array}{l}\text { Early detection of foot ulcer } \\
\text { signs; } \\
\text { Prevention of diabetic foot ulcers } \\
\text { and other foot complications; }\end{array}$ \\
\hline
\end{tabular}




\begin{tabular}{|c|c|c|c|c|c|c|}
\hline $\begin{array}{l}\text { https://scholar.google.co } \\
\text { m/scholar?hl=en\&as }\end{array}$ & & & $\begin{array}{l}\text { validation } \\
\text { techniques. }\end{array}$ & & $\begin{array}{l}\text { high risk for } \\
\text { developing foot } \\
\text { ulcers; } \\
\text { To promote } \\
\text { effective } \\
\text { communication and } \\
\text { improve patient } \\
\text { safety; } \\
\text { To prevent the } \\
\text { incidence of foot } \\
\text { ulcers. (Tariq \& } \\
\text { Cruz, 2015). }\end{array}$ & $\begin{array}{l}\text { Timely referral to appropriate } \\
\text { medical service for further } \\
\text { evaluation (Tariq \& Cruz., 2015). }\end{array}$ \\
\hline $\begin{array}{l}\text { Williams, Y., Jones, S., \& Johnson, } \\
\text { K. (2018). Increasing } \\
\text { healthcare provider } \\
\text { compliance in performing } \\
\text { foot examinations in } \\
\text { diabetic patients. Online } \\
\text { Journal of Nursing } \\
\text { Informatics, } 22(3), 4-13 . \\
\text { https://www.himss.org/lib } \\
\text { rary/increasing- } \\
\text { healthcare-provider- } \\
\text { compliance-performing- } \\
\text { foot-examinations- } \\
\text { diabetic-patients }\end{array}$ & $\begin{array}{l}\text { Design: } \\
\text { Quantitative } \\
\text { Descriptive } \\
\text { Statistics } \\
\text { Level: III } \\
\text { Quality: } \\
\text { High } \\
\text { Grade: A }\end{array}$ & $\begin{array}{l}\text { Sample } \\
\text { Size: } \\
100 \text { patients } \\
\text { for whom } \\
\text { chart } \\
\text { reviews } \\
\text { were } \\
\text { conducted }\end{array}$ & $\begin{array}{l}\text { The intervention } \\
\text { was an electronic } \\
\text { reminder alert in a } \\
\text { Microsoft Excel } \\
\text { data document. }\end{array}$ & $\begin{array}{l}\text { The Chronic } \\
\text { Care Model }\end{array}$ & $\begin{array}{l}\text { To reduce the } \\
\text { incidence of foot } \\
\text { ulcers; } \\
\text { To remind providers } \\
\text { to perform a foot } \\
\text { exam. }\end{array}$ & $\begin{array}{l}\text { The implementation of an alert in } \\
\text { the electronic health record to } \\
\text { remind healthcare providers to } \\
\text { perform diabetic foot } \\
\text { examinations will benefit patients } \\
\text { with diabetes. }\end{array}$ \\
\hline $\begin{array}{l}\text { Wu, S., Chan, K., Bae, J., \& Ford, } \\
\text { E. (2019). Electronic } \\
\text { clinical reminder and } \\
\text { quality of primary } \\
\text { diabetes care. Primary } \\
\text { Care Diabetes, 13(2), } \\
\text { 150-157. } \\
\text { https://doi.org/10.1016/j.p } \\
\text { cd.2018.08.007 }\end{array}$ & $\begin{array}{l}\text { Design: } \\
\text { Quantitative } \\
\text { Retrospectiv } \\
\text { e Cohort } \\
\text { study } \\
\text { Level: III } \\
\text { Quality: } \\
\text { High } \\
\text { Grade: A }\end{array}$ & $\begin{array}{l}\text { Sample } \\
\text { Size: } 5508 \\
\text { visits by } \\
\text { adults with } \\
\text { diabetes }\end{array}$ & $\begin{array}{l}\text { Multiple logistic } \\
\text { regression was } \\
\text { used to test for } \\
\text { associations } \\
\text { between clinical } \\
\text { reminder use and } \\
\text { recommended } \\
\text { services by the } \\
\text { American Diabetes } \\
\text { Association (Wu et } \\
\text { al., 2019). Data } \\
\text { from 2012 to } 2014 \\
\text { NAMCS, an } \\
\text { annual nationally } \\
\text { representative } \\
\text { survey of } \\
\text { ambulatory visits } \\
\text { made to physician }\end{array}$ & $\begin{array}{l}\text { None clearly } \\
\text { stated }\end{array}$ & $\begin{array}{l}\text { To study the } \\
\text { association of } \\
\text { EMR's clinical } \\
\text { reminder use of a } \\
\text { comprehensive set } \\
\text { of diabetes metrics } \\
\text { in U.S. office-based } \\
\text { physicians and } \\
\text { within solo verses } \\
\text { multi-physician } \\
\text { practices (Wu et al., } \\
\text { 2019) } \\
\text { To increase } \\
\text { compliance in } \\
\text { performing foot } \\
\text { exams (Wu et al., } \\
\text { 2019) }\end{array}$ & $\begin{array}{l}\text { Visits to non-solo practices were } \\
\text { more likely to use routine clinical } \\
\text { reminders than visits to solo } \\
\text { practices (Wu et al., 2019). }\end{array}$ \\
\hline
\end{tabular}




\begin{tabular}{|c|c|c|c|c|c|c|}
\hline & & & $\begin{array}{l}\text { offices in the U.S. } \\
\text { (Wu et al., 2019). }\end{array}$ & & & \\
\hline $\begin{array}{l}\text { Zhou, Q., Peng, M., Zhou, L., Bai, } \\
\text { J., Tong, A., Liu, M., \& } \\
\text { Chen, Z. (2018). } \\
\text { Development and } \\
\text { validation of a brief } \\
\text { diabetic foot ulceration } \\
\text { risk checklist among } \\
\text { diabetic patients: A } \\
\text { multicenter longitudinal } \\
\text { study in China. Scientific } \\
\text { Reports, 1, 1. } \\
\text { https://doi.org/10.38/s415 } \\
\text { 98-018-19268-3. }\end{array}$ & $\begin{array}{l}\text { Design: } \\
\text { Quantitative } \\
\text { Longitudina } \\
\text { 1 study } \\
\text { Level: II } \\
\text { Quality: } \\
\text { High } \\
\text { Grade: A }\end{array}$ & $\begin{array}{l}\text { Sample } \\
\text { Size: } 477 \\
\text { patients } \\
\text { with } \\
\text { diabetes }\end{array}$ & $\begin{array}{l}\text { Diabetic foot } \\
\text { ulceration risk } \\
\text { checklist tool; } \\
\text { Internal } \\
\text { consistency } \\
\text { reliability, } \\
\text { construct validity, } \\
\text { concurrent } \\
\text { validity, and } \\
\text { measurement } \\
\text { invariance of the } \\
\text { tool were assessed } \\
\text { (Zhou et al., 2018) }\end{array}$ & $\begin{array}{l}\text { Modern latent } \\
\text { theory is a } \\
\text { paradigm for } \\
\text { the design, } \\
\text { analysis, and } \\
\text { scoring of } \\
\text { tests, } \\
\text { questionnaires } \\
\text {, and similar } \\
\text { instruments } \\
\text { measuring } \\
\text { abilities and } \\
\text { attitudes } \\
\text { (Zhou et al., } \\
\text { 2018). }\end{array}$ & $\begin{array}{l}\text { To develop, assess, } \\
\text { and validate a brief } \\
\text { diabetic foot } \\
\text { ulceration risk } \\
\text { checklist among } \\
\text { diabetic patients }\end{array}$ & $\begin{array}{l}\text { Follow-up data one year } \\
\text { afterwards showed a decrease in } \\
\text { the incidence of foot ulcers after } \\
\text { the implementation of the } \\
\text { intervention. }\end{array}$ \\
\hline
\end{tabular}




\section{Appendix B}

\section{Summary of Systematic Reviews}

\begin{tabular}{|c|c|c|c|c|c|c|c|}
\hline Citation & Quality Grade & Question & $\begin{array}{l}\text { Search } \\
\text { Strategy }\end{array}$ & $\begin{array}{l}\text { Inclusion/ } \\
\text { Exclusion Criteria }\end{array}$ & $\begin{array}{l}\text { Data Extraction and } \\
\text { Analysis }\end{array}$ & $\begin{array}{l}\text { Key } \\
\text { Findings }\end{array}$ & $\begin{array}{l}\text { Usefulness/Recomm } \\
\text { endation/ } \\
\text { Implications }\end{array}$ \\
\hline \begin{tabular}{|l} 
Bus, S., Netten, J., Lavery, \\
L., Monteiro- \\
Soares, M., \\
Rasmussen, A., \\
Jubiz, Y., \& Price, \\
P. (2016). \\
IWGDF guidance \\
on the prevention \\
of foot ulcers in \\
at-risk patients \\
with diabetes. \\
Diabetes \\
Metabolism \\
Research and \\
Reviews, \\
32(Suppl.1), 16- \\
24. \\
https://doi.10.100 \\
2/dmrr.2696
\end{tabular} & $\begin{array}{l}\text { Quality: High } \\
\text { Grade: A } \\
\text { Level IV } \\
\\
\end{array}$ & $\begin{array}{l}\text { Should a } \\
\text { person with } \\
\text { diabetes be } \\
\text { screened for } \\
\text { risk of foot } \\
\text { ulcer? }\end{array}$ & \begin{tabular}{|l|} 
The GRADE \\
methodology \\
around the PICO \\
format; \\
Multidisciplinary \\
Work Group of \\
Experts; \\
Systematic \\
Review of the \\
Literature; \\
Formatted \\
recommendation \\
s to answer each \\
clinical question.
\end{tabular} & $\begin{array}{l}\text { Inclusions: Patients } \\
\text { with previous foot } \\
\text { ulcer/amputations, } \\
\text { diabetes, peripheral } \\
\text { neuropathy, and } \\
\text { peripheral artery } \\
\text { disease }\end{array}$ & $\begin{array}{l}\text { International Working } \\
\text { Group on the Diabetic } \\
\text { Foot }\end{array}$ & $\begin{array}{l}\text { At risk patients } \\
\text { require more } \\
\text { frequent foot } \\
\text { screening than } \\
\text { patients not at } \\
\text { risk. }\end{array}$ & $\begin{array}{l}\text { More frequent } \\
\text { screening can lead to } \\
\text { the early identification } \\
\text { of factors increasing } \\
\text { the chances of } \\
\text { developing a foot ulcer. }\end{array}$ \\
\hline \begin{tabular}{|} 
Hingorani, A., LaMuraglia, \\
G., Henke, P., \\
Meissner, M., \\
Loretz, L., \\
Zinszer, K., \\
Driver, \& Murad, \\
M. (2016). The \\
management of \\
diabetic foot: A \\
clinical practice \\
guideline by the \\
Society of \\
Vascular Surgery \\
in collaboration \\
with the American \\
\end{tabular} & $\begin{array}{l}\text { Quality: Good } \\
\text { Grade: B } \\
\text { Level I } \\
\end{array}$ & $\begin{array}{l}\text { Will provider } \\
\text { compliance in } \\
\text { performing } \\
\text { foot exams } \\
\text { reduce the } \\
\text { incidence of } \\
\text { foot ulcers? }\end{array}$ & \begin{tabular}{|l|} 
The GRADE \\
methodology \\
was focused \\
around the PICO \\
format; Work \\
Group of Expert; \\
Systematic \\
Reviews of \\
literature.
\end{tabular} & $\begin{array}{l}\text { Inclusion criteria of } \\
\text { preventative } \\
\text { recommendations } \\
\text { including adequate } \\
\text { glycemic control, } \\
\text { periodic foot } \\
\text { inspections, and } \\
\text { patient and family } \\
\text { education. }\end{array}$ & $\begin{array}{l}\text { Five systematic reviews } \\
\text { to focus on the } \\
\text { prevention of diabetic } \\
\text { foot ulceration, off- } \\
\text { loading, diagnosis of } \\
\text { osteomyelitis, wound } \\
\text { care, and peripheral } \\
\text { arterial disease } \\
\text { (Hingorani et al., 2016). }\end{array}$ & $\begin{array}{l}\text { Those at } \\
\text { increased risks } \\
\text { of foot ulcers } \\
\text { should have } \\
\text { more frequent } \\
\text { foot exams. }\end{array}$ & $\begin{array}{l}\text { A four-level system for } \\
\text { follow-up has been } \\
\text { developed by the } \\
\text { American College of } \\
\text { Foot and Ankle } \\
\text { Surgeons (Hingorani et } \\
\text { al., 2016). }\end{array}$ \\
\hline
\end{tabular}




\begin{tabular}{|c|c|c|c|c|c|c|c|}
\hline Citation & Quality Grade & Question & $\begin{array}{l}\text { Search } \\
\text { Strategy }\end{array}$ & $\begin{array}{l}\text { Inclusion/ } \\
\text { Exclusion Criteria }\end{array}$ & $\begin{array}{l}\text { Data Extraction and } \\
\text { Analysis }\end{array}$ & $\begin{array}{l}\text { Key } \\
\text { Findings }\end{array}$ & $\begin{array}{l}\text { Usefulness/Recomm } \\
\text { endation/ } \\
\text { Implications }\end{array}$ \\
\hline $\begin{array}{l}\text { Podiatric Medical } \\
\text { Association and } \\
\text { the Society for } \\
\text { Vascular } \\
\text { Medicine. Journal } \\
\text { of Vascular } \\
\text { Surgery, 63(2), } \\
\text { 3S-21S. } \\
\text { https://doi.org/19. } \\
\text { 1016/j.jvs.2015.1 } \\
0.003\end{array}$ & & & & & & & \\
\hline $\begin{array}{l}\text { Nuti, L., Turkcan, A., } \\
\text { Lawley, M., } \\
\text { Zhang, L., Sands, } \\
\text { L., \& McComb. } \\
\text { (2015). The } \\
\text { impact of } \\
\text { interventions on } \\
\text { appointment and } \\
\text { clinical outcomes } \\
\text { for individuals } \\
\text { with diabetes: A } \\
\text { systematic } \\
\text { reviews. BMC } \\
\text { Health Services } \\
\text { Research, 15, } \\
\text { 355. } \\
\text { https://doi.org/10. } \\
\text { 1186/s12913-015- } \\
\text { 0938-5 }\end{array}$ & $\begin{array}{l}\text { Quality: High } \\
\text { Grade: A } \\
\text { Level I } \\
\\
\end{array}$ & $\begin{array}{l}\text { What is the } \\
\text { impact of } \\
\text { interventions } \\
\text { on } \\
\text { appointments } \\
\text { and clinical } \\
\text { outcomes for } \\
\text { individuals } \\
\text { with diabetes? }\end{array}$ & $\begin{array}{l}\text { MEDLINE; the } \\
\text { PubMed } \\
\text { interface; MeSH } \\
\text { terms; CINAHL; } \\
\text { Cochrane } \\
\text { database } \\
\end{array}$ & $\begin{array}{l}\text { The inclusion criteria } \\
\text { for intervention } \\
\text { articles included } \\
\text { diabetes, adults, and } \\
\text { English language. } \\
\text { Exclusion criteria } \\
\text { comprised gestational } \\
\text { diabetes, } \\
\text { pharmacological } \\
\text { processes and } \\
\text { phenomena, } \\
\text { transplantation, and } \\
\text { cardiovascular disease. }\end{array}$ & $\begin{array}{l}\text { A comprehensive } \\
\text { literature search } \\
\text { generated } 4111 \text { articles. } \\
\text { The exclusion factors } \\
\text { were enforced. Limiters } \\
\text { were put in place, e.g., } \\
\text { adults, English } \\
\text { language, and } \\
\text { containing an abstract. }\end{array}$ & $\begin{array}{l}\text { Simple phone } \\
\text { and letter } \\
\text { reminders } \\
\text { scheduling or } \\
\text { prompting the } \\
\text { date and time } \\
\text { of an } \\
\text { appointment } \\
\text { can have a } \\
\text { positive } \\
\text { impact on } \\
\text { clinical and } \\
\text { behavioral } \\
\text { outcomes. }\end{array}$ & $\begin{array}{l}\text { Multiple interventions } \\
\text { aimed at appointment } \\
\text { management to } \\
\text { improve diabetes } \\
\text { disease management. }\end{array}$ \\
\hline $\begin{array}{c}\text { Schaper, N. C., Van Netten, } \\
\text { J. J., Apelquist, J., } \\
\text { Lipsky, B. A., } \\
\text { Bakker, K., \& The } \\
\text { International } \\
\text { Working Group } \\
\text { on the Diabetic } \\
\text { Foot (IWGDF). } \\
\text { (2017). } \\
\text { Prevention and }\end{array}$ & $\begin{array}{l}\text { Quality: High } \\
\text { Grade: A } \\
\text { Level: IV } \\
\end{array}$ & $\begin{array}{l}\text { Will the close } \\
\text { monitoring of } \\
\text { diabetics' feet } \\
\text { reduce foot } \\
\text { problems and } \\
\text { sequelae? }\end{array}$ & $\begin{array}{l}\text { The GRADE } \\
\text { system was used } \\
\text { to translate the } \\
\text { evidence. }\end{array}$ & Implied adherence & $\begin{array}{l}\text { Seven systematic } \\
\text { reviews; The IWGDF } \\
\text { made a total of } 77 \\
\text { recommendations on } \\
\text { the prevention and } \\
\text { management of foot } \\
\text { problems in diabetes. }\end{array}$ & $\begin{array}{l}\text { Team } \\
\text { approach to } \\
\text { prevent and } \\
\text { treat foot } \\
\text { complications; } \\
\text { Recommendati } \\
\text { ons for foot } \\
\text { care programs } \\
\text { to follow } \\
\text { guidelines; }\end{array}$ & $\begin{array}{l}\text { Multiple studies show } \\
\text { that multidisciplinary } \\
\text { teams in managing } \\
\text { diabetic foot care } \\
\text { results in decrease of } \\
\text { diabetic foot-related } \\
\text { complications; } \\
\text { Summary guidance } \\
\text { suggests if used, there }\end{array}$ \\
\hline
\end{tabular}




\begin{tabular}{|c|c|c|c|c|c|c|c|}
\hline Citation & Quality Grade & Question & $\begin{array}{l}\text { Search } \\
\text { Strategy }\end{array}$ & $\begin{array}{l}\text { Inclusion/ } \\
\text { Exclusion Criteria }\end{array}$ & $\begin{array}{l}\text { Data Extraction and } \\
\text { Analysis }\end{array}$ & \begin{tabular}{|l} 
Key \\
Findings
\end{tabular} & $\begin{array}{l}\text { Usefulness/Recomm } \\
\text { endation/ } \\
\text { Implications }\end{array}$ \\
\hline \begin{tabular}{|l} 
management of \\
foot problems in \\
diabetes: A \\
summary \\
guidance for daily \\
practice 2015, \\
based on the \\
IWGDF guidance \\
documents. \\
Diabetes/Metaboli \\
sm: Research and \\
Reviews, S1, 7. \\
https://doi.org/10.1002/dmrr \\
.2695
\end{tabular} & & & & & & $\begin{array}{l}\text { Education for } \\
\text { patients, } \\
\text { families, } \\
\text { providers, and } \\
\text { staff; } \\
\text { A system to } \\
\text { detect at risk } \\
\text { patients; } \\
\text { Auditing to } \\
\text { ensure local } \\
\text { practices meet } \\
\text { standards. }\end{array}$ & $\begin{array}{l}\text { will likely be a } \\
\text { reduction in worldwide } \\
\text { outcomes of foot } \\
\text { problems in patients } \\
\text { with diabetes, resulting } \\
\text { in reduction of } \\
\text { mortality and morbidity } \\
\text { associated with major } \\
\text { health problems. }\end{array}$ \\
\hline \begin{tabular}{|l} 
Stanbhag, D., Graham, I. \\
D., Harlos, K., \\
Haynes, R. B., \\
Gabizon, I., \\
Connolly, S. J., \\
Gillian, H., \& Van \\
Spall, C. (2018). \\
Effectiveness of \\
Implementation \\
interventions in \\
improving \\
physician \\
adherence to \\
guideline \\
recommendations \\
in heart failure: A \\
systematic review. \\
BMJ Open, $8,1-$ \\
17. \\
https://dx.doi.org/ \\
10.1135/bmjopen- \\
2017-017765
\end{tabular} & $\begin{array}{l}\text { Quality: High } \\
\text { Grade: A } \\
\text { Level: I } \\
\\
\end{array}$ & $\begin{array}{l}\text { Will the } \\
\text { implementa- } \\
\text { tion of } \\
\text { interventions } \\
\text { improve } \\
\text { provider } \\
\text { adherence? }\end{array}$ & $\begin{array}{l}\text { MEDLINE; } \\
\text { EMBASE; } \\
\text { HealthSTAR; } \\
\text { CINAHL; The } \\
\text { Cochrane } \\
\text { Library; The } \\
\text { Joanna Briggs } \\
\text { Institute } \\
\text { Evidence-based } \\
\text { Practice } \\
\text { Database; The } \\
\text { Agency for } \\
\text { Healthcare } \\
\text { Research and } \\
\text { Quality } \\
\text { Evidence-base } \\
\text { Practice Centers' } \\
\text { Research } \\
\text { Reports. }\end{array}$ & $\begin{array}{l}\text { Inclusion criteria of } \\
\text { heart failure, guidance } \\
\text { adherence, practice } \\
\text { guideline, evidence- } \\
\text { based medicine, and } \\
\text { EPOC intervention } \\
\text { types }\end{array}$ & $\begin{array}{l}38 \text { studies included; } \\
\text { Provider-level } \\
\text { interventions } \\
\text { (n=13studies) included } \\
\text { audit and feedback, } \\
\text { reminders, and } \\
\text { education. }\end{array}$ & $\begin{array}{l}\text { Significant } \\
\text { improvements } \\
\text { in clinical } \\
\text { pathway, } \\
\text { multidisciplina } \\
\text { ry team, and } \\
\text { multifaceted } \\
\text { intervention }\end{array}$ & $\begin{array}{l}\text { Multi-disciplinary } \\
\text { teams, multifaceted } \\
\text { interventions, and } \\
\text { clinical pathways } \\
\text { yielded most } \\
\text { consistency in } \\
\text { increasing guideline } \\
\text { uptake by the provider. }\end{array}$ \\
\hline
\end{tabular}




\begin{tabular}{|c|c|c|c|c|c|c|c|}
\hline Citation & Quality Grade & Question & $\begin{array}{l}\text { Search } \\
\text { Strategy }\end{array}$ & $\begin{array}{l}\text { Inclusion/ } \\
\text { Exclusion Criteria }\end{array}$ & $\begin{array}{l}\text { Data Extraction and } \\
\text { Analysis }\end{array}$ & $\begin{array}{l}\text { Key } \\
\text { Findings }\end{array}$ & $\begin{array}{l}\text { Usefulness/Recomm } \\
\text { endation/ } \\
\text { Implications }\end{array}$ \\
\hline \begin{tabular}{|l|} 
Rinaldi, G., Hijazi, A., \& \\
Hafhparast- \\
Bidgoli, H. \\
(2020). Cost and \\
cost- \\
effectiveness of \\
mHealth \\
interventions for \\
the prevention \\
and control of \\
type 2 diabetes \\
mellitus: A \\
systematic \\
review. \\
Diabetes \\
Research and \\
Clinical \\
Practice, \\
162(4), 1-24. \\
https://doi.org/1 \\
0.1016/j.diabres. \\
2020.108084
\end{tabular} & $\begin{array}{l}\text { Quality: Good } \\
\text { Grade: B } \\
\text { Level: II } \\
\\
\\
\end{array}$ & $\begin{array}{l}\text { Will the } \\
\text { implementat } \\
\text { ion of a } \\
\text { mobile } \\
\text { health tool } \\
\text { improve } \\
\text { adherence to } \\
\text { diabetes } \\
\text { management } \\
\text { plans? }\end{array}$ & \begin{tabular}{|l} 
EMBASE; \\
PubMED; Web \\
of Science
\end{tabular} & \begin{tabular}{|l|} 
Inclusion criteria of \\
partial or full \\
evaluations; \\
mHealth \\
interventions \\
targeting prevention \\
and management of \\
patients with or at \\
risk of T2DM.
\end{tabular} & $\begin{array}{l}23 \text { studies included; } \\
\text { mHealth compared to } \\
\text { usual care, economic } \\
\text { evaluations; mHealth } \\
\text { with adherence to } \\
\text { exercise program and } \\
\text { diabetes management }\end{array}$ & $\begin{array}{l}\text { Implementati } \\
\text { on of } \\
\text { mHealth } \\
\text { improves } \\
\text { adherence to } \\
\text { exercise and } \\
\text { diabetes } \\
\text { management } \\
\text { and long- } \\
\text { term cost } \\
\text { reduction. }\end{array}$ & $\begin{array}{l}\text { Interventions of } \\
\text { technology in } \\
\text { management of } \\
\text { diabetes care yields } \\
\text { improvement in } \\
\text { outcomes. }\end{array}$ \\
\hline $\begin{array}{l}\text { Lorenzetti, D. L., Quan, } \\
\text { H., Lucyk, K., } \\
\text { Cunningham, } \\
\text { C., Hennessy, } \\
\text { D., Juang, J., \& } \\
\text { Beck, C. A. } \\
\text { (2018). } \\
\text { Strategies for } \\
\text { improving } \\
\text { physician } \\
\text { documentation } \\
\text { in the } \\
\text { emergency } \\
\text { department: A } \\
\text { systematic }\end{array}$ & $\begin{array}{l}\text { Quality: Good } \\
\text { Grade: B } \\
\text { Level: II }\end{array}$ & $\begin{array}{l}\text { Will the } \\
\text { implementat } \\
\text { ion of } \\
\text { electronic } \\
\text { intervention } \\
\text { s improve } \\
\text { provider } \\
\text { adherence to } \\
\text { documentin } \\
\mathrm{g} \text { ? }\end{array}$ & $\begin{array}{l}\text { The Cochrane } \\
\text { Library; DARE } \\
\text { Database of } \\
\text { Reviews of } \\
\text { Effects; } \\
\text { EMBASE; } \\
\text { MEDLINE; } \\
\text { PubMED; and } \\
\text { Web of } \\
\text { Science. }\end{array}$ & \begin{tabular}{|l|} 
Inclusion criteria \\
involved the \\
reported results of \\
any intervention to \\
improve physician \\
documentation; \\
Exclusion criteria \\
included descriptive \\
or case reports, \\
reporting of only \\
postintervention \\
results, focusing on \\
populations other \\
than physicians, \\
residents, or medical
\end{tabular} & $\begin{array}{l}19 \text { studies were } \\
\text { included; The } \\
\text { effectiveness of } \\
\text { interventions to } \\
\text { improve MDs' } \\
\text { documentation was } \\
\text { reported and the } \\
\text { interventions } \\
\text { included } \\
\text { audit/feedback. } \\
\end{array}$ & $\begin{array}{l}\text { Assess the } \\
\text { effectiveness } \\
\text { of } \\
\text { approaches } \\
\text { to improve } \\
\text { documentatio } \\
\text { n with the } \\
\text { use of } \\
\text { electronic } \\
\text { databases }\end{array}$ & $\begin{array}{l}\text { Seven interventions } \\
\text { to improve physician } \\
\text { documentation were } \\
\text { undertaken: } \\
\text { reminders, } \\
\text { audit/feedback, } \\
\text { dictation, education, } \\
\text { facilitation, } \\
\text { templates/forms, and } \\
\text { multiple } \\
\text { interventions } \\
\text { combinations. }\end{array}$ \\
\hline
\end{tabular}




\begin{tabular}{|c|c|c|c|c|c|}
\hline Citation & Quality Grade Question & $\begin{array}{l}\text { Search } \\
\text { Strategy }\end{array}$ & $\begin{array}{l}\text { Inclusion/ } \\
\text { Exclusion Criteria }\end{array}$ & \begin{tabular}{|l|l|} 
Data Extraction and & Key \\
Analysis & Findings
\end{tabular} & \begin{tabular}{|l|} 
Usefulness/Recomm \\
endation/ \\
Implications
\end{tabular} \\
\hline $\begin{array}{l}\text { review. BMC } \\
\text { Emergency } \\
\text { Medicine, } \\
\text { 18(36), 1-12. } \\
\text { https://doi.org/1 } \\
0.1186 / \text { s12873- } \\
018-0188-\mathrm{z}\end{array}$ & & & $\begin{array}{l}\text { students; studies } \\
\text { centered on } \\
\text { education to } \\
\text { improve history } \\
\text { taking. }\end{array}$ & & \\
\hline
\end{tabular}




\section{Appendix C}

\section{SWOT Analysis}

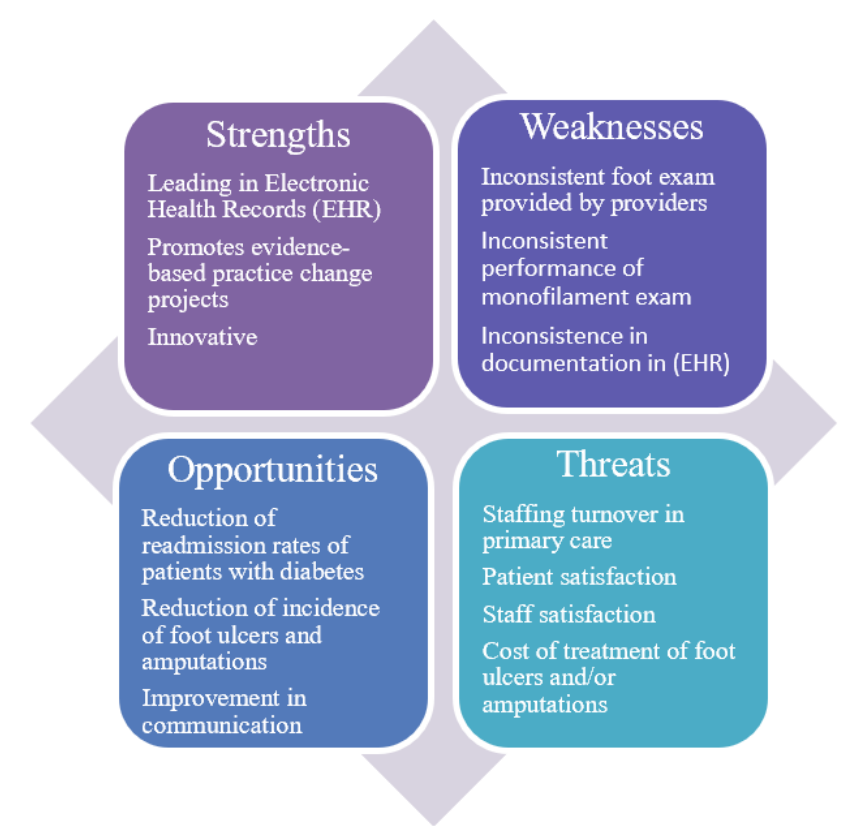




\section{Appendix D}

\section{Project Timeline}

\begin{tabular}{|c|c|c|c|c|c|c|c|c|}
\hline \multirow[b]{2}{*}{ Activity } & \multicolumn{2}{|c|}{ NUR7802 } & \multicolumn{6}{|c|}{ NUR7803 } \\
\hline & 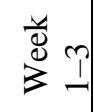 & $\begin{array}{l}\frac{1}{\Xi} \\
3 \\
3\end{array}$ & $\sum_{3}^{\frac{1}{8}} \frac{1}{1}$ & 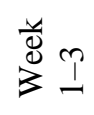 & 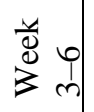 & $\frac{1}{D} \frac{1}{3} \frac{1}{r}$ & $\frac{1}{2} \frac{1}{1}$ & 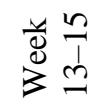 \\
\hline Meet with preceptor and USAHS Faculty as needed & $\mathrm{X}$ & $\mathrm{X}$ & $\mathrm{X}$ & & & & & \\
\hline Prepare project proposal & $\mathrm{X}$ & $\mathrm{X}$ & & & & & & \\
\hline Preceptor collaboration as needed & $\mathrm{X}$ & $\mathrm{X}$ & $\mathrm{X}$ & $\mathrm{X}$ & $\mathrm{X}$ & $\mathrm{X}$ & $\mathrm{X}$ & $\mathrm{X}$ \\
\hline $\begin{array}{l}\text { Initial meeting/Form team/Interprofessional team } \\
\text { collaborations/meetings/status reports }\end{array}$ & $\mathrm{X}$ & $\mathrm{X}$ & $\mathrm{X}$ & $\mathrm{X}$ & $\mathrm{X}$ & $\mathrm{X}$ & $\mathrm{X}$ & \\
\hline Review DNP Project Proposal by USAHS Nursing EPRC & $\mathrm{X}$ & $\mathrm{X}$ & & & & & & \\
\hline Submit the DNP Proposal for EPRC for approval & $\mathrm{X}$ & $\mathrm{X}$ & & & & & & \\
\hline $\begin{array}{l}\text { Meet with the Key Stakeholders to gain buy-in and support for the } \\
\text { evidence-based change project }\end{array}$ & $\mathrm{X}$ & $\mathrm{X}$ & & & & & & \\
\hline $\begin{array}{l}\text { Prepare training materials/Complete training modules required from } \\
\text { the facility }\end{array}$ & $\mathrm{X}$ & $\mathrm{X}$ & & & & & & \\
\hline Submit to Facility for IRB Approval after USA approval & $\mathrm{X}$ & $\mathrm{X}$ & & & & & & \\
\hline Allow time for IRB approval & & $\mathrm{X}$ & & & & & & \\
\hline $\begin{array}{l}\text { Schedule locations and Post training dates for staff, providers, and } \\
\text { patients' education }\end{array}$ & & $\mathrm{X}$ & & & & & & \\
\hline $\begin{array}{l}\text { Training and education for staff, providers, and patients. Audit with } \\
\text { feedback and remedial training. }\end{array}$ & & $\mathrm{X}$ & $\mathrm{X}$ & $\mathrm{X}$ & $\mathrm{X}$ & $\mathrm{X}$ & $\mathrm{X}$ & \\
\hline $\begin{array}{l}\text { Proposal for budget for the project; Include interprofessional team in } \\
\text { planning }\end{array}$ & & $\mathrm{X}$ & $\mathrm{X}$ & & & & & \\
\hline Approval of budget & & & $\mathrm{X}$ & & & & & \\
\hline Development of the ECR alert by the informational technologist & & & $\mathrm{X}$ & $\mathrm{X}$ & & & & \\
\hline $\begin{array}{l}\text { Implementation of the ECR alert; Training and Education on the use } \\
\text { of the ECR alert; Perform preintervention chart reviews to obtain } \\
\text { baseline data; Ensure facility's IRB approval prior to start of chart } \\
\text { reviews }\end{array}$ & & & & $\mathrm{X}$ & $\mathrm{X}$ & & & \\
\hline Data Analysis-Perform evaluation and analysis of data & & & & & & $\mathrm{X}$ & $\mathrm{X}$ & \\
\hline Dissemination of project findings & & & & & & & & $\mathrm{X}$ \\
\hline Project Closure & & & & & & & & $\mathrm{X}$ \\
\hline
\end{tabular}




\section{Appendix E}

\section{Excel Codebook}

\begin{tabular}{|c|c|c|c|c|c|c|c|c|c|}
\hline \multicolumn{10}{|c|}{ Data Set: Complaince with Annual Diabetic Foot Exam for T2DM patients } \\
\hline Pre/Post & Date & Patient \# & Pt Age & Pt Sex & Clinic & Provider & $\begin{array}{l}\text { Diabetic Foot } \\
\text { Exam Completed }\end{array}$ & $\begin{array}{l}\text { Podiatry } \\
\text { Referral }\end{array}$ & Notes \\
\hline Example & $1 / 1$ & 2 & & & & & Yes & Yes & \\
\hline Pre & & 1 & & & & & & & \\
\hline Pre & & 2 & & & & & & & \\
\hline Pre & & 3 & & & & & & & \\
\hline Pre & & 4 & & & & & & & \\
\hline Pre & & 5 & & & & & & & \\
\hline Pre & & 6 & & & & & & & \\
\hline Pre & & 7 & & & & & & & \\
\hline Pre & & 8 & & & & & & & \\
\hline Pre & & 9 & & & & & & & \\
\hline Pre & & 10 & & & & & & & \\
\hline Pre & & 11 & & & & & & & \\
\hline Pre & & 12 & & & & & & & \\
\hline Pre & & 13 & & & & & & & \\
\hline Pre & & 14 & & & & & & & \\
\hline Pre & & 15 & & & & & & & \\
\hline Pre & & 16 & & & & & & & \\
\hline Pre & & 17 & & & & & & & \\
\hline Pre & & 18 & & & & & & & \\
\hline Pre & & 19 & & & & & & & \\
\hline Pre & & 20 & & & & & & & \\
\hline Pre & & 21 & & & & & & & \\
\hline Pre & & 22 & & & & & & & \\
\hline Pre & & 23 & & & & & & & \\
\hline Pre & & 24 & & & & & & & \\
\hline Pre & & 25 & & & & & & & \\
\hline Pre & & 26 & & & & & & & \\
\hline Pre & & 27 & & & & & & & \\
\hline Pre & & 28 & & & & & & & \\
\hline Pre & & 29 & & & & & & & \\
\hline Pre & & 30 & & & & & & & \\
\hline Pre & & 31 & & & & & & & \\
\hline Pre & & 32 & & & & & & & \\
\hline Pre & & 33 & & & & & & & \\
\hline Pre & & 34 & & & & & & & \\
\hline Pre & & 35 & & & & & & & \\
\hline Pre & & 36 & & & & & & & \\
\hline Pre & & 37 & & & & & & & \\
\hline Pre & & 38 & & & & & & & \\
\hline Pre & & 39 & & & & & & & \\
\hline Pre & & 40 & & & & & & & \\
\hline Pre & & 41 & & & & & & & \\
\hline Pre & & 42 & & & & & & & \\
\hline Pre & & 43 & & & & & & & \\
\hline Pre & & 44 & & & & & & & \\
\hline Pre & & 45 & & & & & & & \\
\hline Pre & & 46 & & & & & & & \\
\hline Pre & & 47 & & & & & & & \\
\hline Pre & & 48 & & & & & & & \\
\hline Pre & & 49 & & & & & & & \\
\hline Pre & & 50 & & & & & & & \\
\hline Post & & 51 & & & & & & & \\
\hline Post & & 52 & & & & & & & \\
\hline b & Sheet1 & $\oplus$ & & & & & & & $\vdots$ \\
\hline
\end{tabular}




\section{Appendix F}

\section{Participants' Demographic Characteristics}

\begin{tabular}{|c|c|c|c|}
\hline A & B & c & D \\
\hline Questions & Variable & Values & Missing Data -99 \\
\hline Participant Code & Self -generated Code & \#\#\#\# & \\
\hline \multirow[t]{5}{*}{ 1. Classification } & Job Classification & $\mathrm{LPN}=0$ & \\
\hline & & $\mathrm{RN}=1$ & \\
\hline & & $\mathrm{MD}=3$ & \\
\hline & & $\mathrm{NP}=4$ & \\
\hline & & $\mathrm{PA}=5$ & \\
\hline \multirow[t]{2}{*}{ 2. Received Education } & Education on Foot Exam & Yes $=0$ & \\
\hline & & $\mathrm{No}=1$ & \\
\hline \multirow[t]{2}{*}{ 3. Knowledge r/t Foot Exam } & Knowledge & Yes $=0$ & \\
\hline & & $\mathrm{No}=1$ & \\
\hline \multirow[t]{2}{*}{ 4. Education on ECR Alert } & Education on Reminder & Yes $=0$ & \\
\hline & & $\mathrm{No}=1$ & \\
\hline & & & \\
\hline & & & \\
\hline & & & \\
\hline & & & \\
\hline & & & \\
\hline & & & \\
\hline & & & \\
\hline & & & \\
\hline & & & \\
\hline & & & \\
\hline & & & \\
\hline & & & \\
\hline & & & \\
\hline & & & \\
\hline & & & \\
\hline & & & \\
\hline & & & \\
\hline Staff Education & Patient Demographics & Patient & 1 t... \\
\hline
\end{tabular}




\section{Appendix G}

\section{PreTest Provider and Staff Knowledge}

1. Are you comfortable using the monofilament?
a. Yes
b. No

2. Do you inspect your patient's feet during each clinic visit?
a. Yes
b. No

3. Do you perform a diabetic foot risk assessment for your patients?
a. Yes
b. No

4. Do you know how to assess for loss of protective sensation?
a. Yes
b. No

5. Do you know how to assess for bone deformity?
a. Yes
b. No

6. Do you know how to perform a diabetic foot exam?
a. Yes
b. No 


\section{Appendix $\mathbf{H}$}

\section{PostTest Provider and Staff Knowledge}

1. Are you comfortable using the monofilament?
a. Yes
b. No

2. Do you inspect your patient's feet during each clinic visit?
a. Yes
b. No

3. Do you perform a diabetic foot risk assessment for your patients?
a. Yes
b. No

4. Do you know how to assess for loss of protective sensation?
a. Yes
b. No

5. Do you know how to assess for bone deformity?
a. Yes
b. No

6. Do you know how to perform a diabetic foot exam?
a. Yes
b. No 


\section{Appendix I}

\section{Inlow's 60-Second Diabetic Foot Screen}

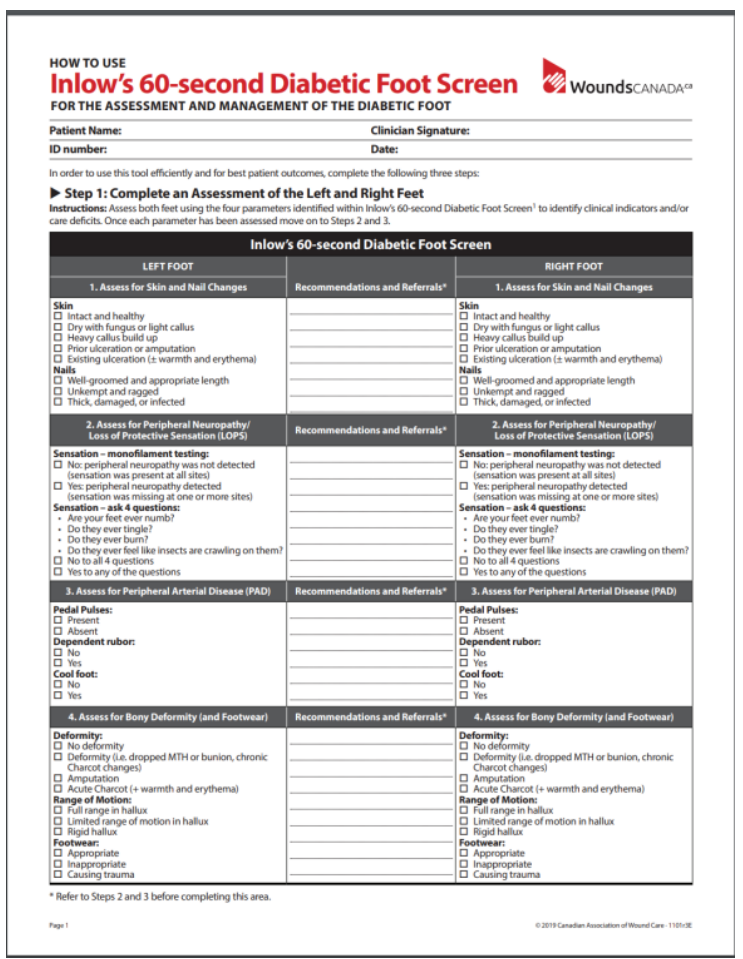

- Step 2: Determine the Risk for Ulceration and Amputation

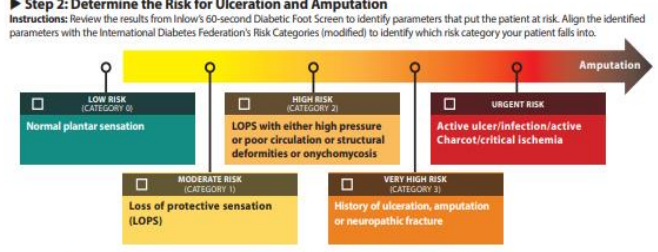

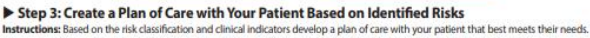

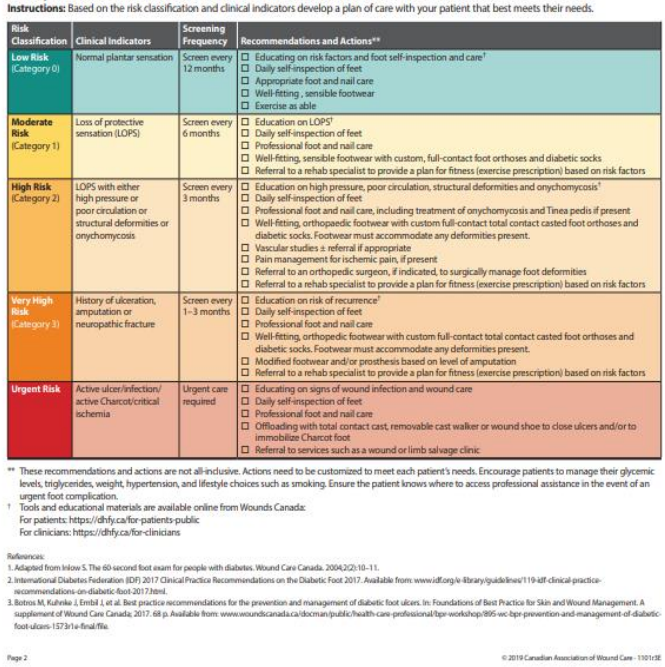




\section{Appendix J}

\section{Permission Letter}

Wounds Canada (Canadian Association of Wound Care)

P. O. Box 35569 York Mills Plaza

North York, ON M2L 2 Y4

July 3,2020

Dear Sirs,

I am writing to request permission for the use of the Inslow's 60 Second Foot Exam Screening Tool on July 3, 2020 thru December 30, 2020. I will be held up because your tool is copyrighted and requires permission to use. I plan to use your tool as an educational resource to teach staff in a primary care clinic on how to perform a foot exam.

I will be done with your tool at the completion of my quality improvement project in December $30,2020$.

Thank you in advance,

Sincerely yours,

Ruby Denson, DNP Student

University of Saint Augustine School for Health Science

I do purpose stated above.

Name:

Signature

Date: 


\section{Appendix K}

\section{Proof of Permission to use Instrument (Inlow's)}

From: info@woundscanada.ca <info@woundscanada.ca>

Sent: Monday, July 6, 2020 2:06:13 PM

To: Ruby Denson <rdenson@umc.edu>

Subject: [EXTERNAL]RE: New submission from 'Contact us'!

Hi Ruby,

Certainly, this tool is available for use on our website here.

Thank you,

Wounds Canada (Canadian Association of Wound Care)

PO Box 35569 York Mills Plaza

North York, ON M2L 2Y4

P 416.485.2292 F 1.888.710.2289

www.woundscanada.ca 


\section{Appendix L}

\section{Measures}

\begin{tabular}{|c|c|c|c|c|}
\hline Measure & Actions & Benchmark & Goal & Data Type \\
\hline $\begin{array}{l}\text { Outcome } \\
\text { Measure }\end{array}$ & $\begin{array}{l}\text { Percentage of staff who completed } \\
\text { pretest knowledge assessment. The } \\
\text { numerator is the number of staff who } \\
\text { completed the pretest assessment at a } \\
\text { given time. The denominator is the total } \\
\text { number of staff at the same time. }\end{array}$ & $+5 \%$ & $\geq 90 \%$ & $\begin{array}{l}\text { Continuous data } \\
x^{2}\end{array}$ \\
\hline $\begin{array}{l}\text { Outcome } \\
\text { Measure }\end{array}$ & $\begin{array}{l}\text { Provider compliance in completing foot } \\
\text { exam. Provider compliance is the } \\
\text { percentage of compliance of the provider } \\
\text { in documenting foot exams. The } \\
\text { numerator is the percentage of providers } \\
\text { who document foot exams. The } \\
\text { denominator is the percentage of foot } \\
\text { exams performed. }\end{array}$ & $+5 \%$ & $\geq 30 \%$ & $\begin{array}{l}\text { Continuous data } \\
\mathrm{x}^{2}\end{array}$ \\
\hline Process Measure & $\begin{array}{l}\text { Percentage of staff compliance in } \\
\text { preparing patients for foot exams. The } \\
\text { numerator is the number of staff } \\
\text { preparing patients for foot exams. The } \\
\text { denominator is the number of foot } \\
\text { exams performed. }\end{array}$ & $50 \%$ & $\geq 90 \%$ & $\begin{array}{l}\text { Continuous data } \\
\mathrm{x}^{2}\end{array}$ \\
\hline Process Measure & $\begin{array}{l}\text { Percentage of provider adherence in } \\
\text { documenting foot exams. The numerator } \\
\text { is the number of providers who } \\
\text { document foot exams at a given time. } \\
\text { The denominator is the total number of } \\
\text { foot exams at the same given time. }\end{array}$ & $\geq 50 \%$ & $\geq 85 \%$ & $\begin{array}{l}\text { Continuous data } \\
x^{2}\end{array}$ \\
\hline Balance Measure & $\begin{array}{l}\text { Cost of training (total number of nursing } \\
\text { staff that requires training x } 2 \text { hours } \times \$ 28, \\
\text { which is the average RN hourly rate for } \\
\text { primary care clinic nurses) }\end{array}$ & $5 \%$ & $\geq 50 \%$ & $\begin{array}{l}\text { Continuous data } \\
\text { Paired t-test }\end{array}$ \\
\hline $\begin{array}{l}\text { Sustainability } \\
\text { Measure }\end{array}$ & $\begin{array}{l}\text { Percentage of Provider Adherence in } \\
\text { performing a foot exam. The numerator is } \\
\text { the number of providers who performed } \\
\text { foot exams and the denominator is the total } \\
\text { number of exams performed. }\end{array}$ & $85 \%$ & $\geq 85 \%$ & $\begin{array}{l}\text { Continuous data } \\
x^{2}\end{array}$ \\
\hline
\end{tabular}

